\title{
Teraviljahinnad Eesti KOHALIKEL TURGUDEL JA NEID MÕJUTANUD TEGURID 1840-1900
}

\author{
Kersti Lust
}

Viljahinnad on sotsiaalmajandusliku arengu peegeldus. Viljahindade abil on võimalik iseloomustada põllumajandusliku tootmise taset ja maa majanduslikku seisundit laiemalt, kaubanduslikke sidemeid, turgude toimimist ja lõimitust ning arvutada reaalpalka. Artiklis vaadeldakse rukki ja kaera hindu kohalikel turgudel aastatel 1841-1900 ning neid mõjutanud faktoreid. ${ }^{1}$ Andmed odra hindade kohta on kasutatud allikates lünklikumad ega leia analüüsimist.

Teraviljahindu on nii Eestis kui ka rahvusvahelises ajalookirjutuses uuritud valdavalt (suur)linnade andmestiku põhjal; siinne kirjutis keskendub aga kohalikele turgudele ja nende integreerituse väljaselgitamisele. Viimast peetakse oluliseks, kuid väga raskeks ülesandeks. ${ }^{2}$ Käsitluse alustamine 1840. aastatega on tingitud eeskätt andmete kättesaadavusest ja varasematest uurimistulemustest. ${ }^{3}$ Sel ajal hakkas aegamisi tugevnema ka talumajanduse seotus turuga ning üha nähtavamaks sai kaubalise

Artikkel ilmub Eesti Teadusfondi grantide 8209 ja 9164 toetusel.

1 Vaatluse alt jäävad kõrvale märkimisväärsed kõikumised aasta sees. Aegridade konstrueerimisel on aluseks võetud saagikoristuse-järgsed hinnad läbi aastate (sügisesed või oktoobri/novembri hinnad sõltuvalt aruandluses kasutatud ajamääratlusest). Saagikuse ja hinna korrelatsiooni väljaselgitamisel on kohane kasutada sügisesi hindu, mis sõltusid sama aasta lõikusest. Lõikuse järel olid ka maa ja linna hinnad ühtlasemad (Juhan Kahk, Die Krise der feudalen Landwirtschaft (Tallinn: Eesti Raamat, 1969), 96). Talud müüsid vilja samuti pärast koristust. Kuna käsitletava perioodi sisse jäävad kaks tõsist näljahäda, siis aasta keskmised hinnad ei tooks piisavalt eredalt välja ikaldustele järgnenud hinnahüpet. Seejuures ei tohi muidugi unustada, et üks ikaldusaasta mõjutas hindu ka järgneval kahel-kolmel aastal. Sügiseste hindade puudumisel on analüüsitud aasta keskmisi hindu.

2 Giovanni Federico, "When did European markets integrate?", European Review of Economic History, 15:1 (2011), 93-129 (119).

3 Olulisemate põllumajandussaaduste hinnad aastatest 1761-1829 on publitseerinud $H$. Hagemeister, "Über den Werth der Livländischen Landgüter und ihrer Erzeugnisse", Livländische Jahrbücher der Landwirtschaft, 6:1 (Dorpat, 1831), 70-74; Jaanus Soo, Põllumajandussaaduste hinnad Eestis aastatel 1710-1819 (diplomitöö) (Tartu, 1985); Kahk, Die Krise, 88-98. 19. sajandi ekspordihinnad on kättesaadavad erinevates statistilistes kogumikes ja perioodilistes väljaannetes. 
tootmisega kaasnev diferentseerumine. 1840. aastate kriisi järel erinevate piirkondade arengus märgatavaks muutunud käärid süvenesid järgnevatel kümnenditel veelgi.

Artikkel käsitleb viljahindade küsimust talurahva vaatepunktist. Sõltuvalt saakidest jm asjaoludest võisid talud olla nii vilja ostjad kui müüjad. ${ }^{4}$ Viljaga kaubeldi laadal ja linnaturul, kõrtsides vahetati vilja viina, õlle jm muude kaupade vastu, samuti ostsid maal ringi liikunud kaupmehed üles talude toodangut ja pakkusid vastu kõikvõimalikku eluks vajalikku. Raharendile üleminekuga kadunud vajadus mõisaid teolistega varustada vähendas taludes sulas- ja teenijarahva ning seega ka toidetavate suude arvu. Mõisatöölised ja talude aastatöölised said tavaliselt toiduvilja tööandjalt osana palgast. ${ }^{5}$ Talurahvast ligemale kolmandiku moodustanud

4 Talude poolt turustatavast kaubast moodustas peamise osa mitte teravili, vaid teised saadused. Eestis puuduvad uurimused selle kohta, kui suur osa talude teraviljatoodangust teorendi ajal müüdi või vahetati teiste kaupade vastu nagu kala, sool, viin, rauakaubad jm. Väljapaistev Läti agraarajaloolane Heinrihs Strods on püüdnud selgitada teravilja kaubalisuse ulatust Liivi- ja Kuramaal, kuid oma järeldustes tugineb ta põhiliselt vaid viimase näidetele. Kuramaa taludes toodetud teravilja kaubastamise määra on ta hinnanud kõrgeks, headel aastatel müüdud veerand või isegi enam saagist. Liivimaa näited mahuvad umbes ühele leheküljele (Heinrihs Strods, Lauksaimniecība Latvijā pārejas periodā no feodālisma uz kapitālismu (18. gs. 8o. gadi - 19. gs. 6o. gadu sākums) (Rīga: Zinātne, 1972), 198-226). Kaubastamise teemat väga põhjalikult lahanud Melita Svarāne on tulnud Strodsiga üldjoontes sarnastele järeldustele (Melita Svarāne, Saimnieks un kalps Kurzemē und Vidzemè XIX gadsimta vidū (Rìga: Zinātne, 1971), 113-122). Ehkki Liivimaa on tagaplaanil ka tema raamatus, nähtub mõlemast teosest selgelt, et Kuramaaga võrreldes oli Liivimaal talude teraviljatoodangu kaubastamine tagasihoidlikum. Talud müüsid muu vajaliku kraami muretsemiseks vilja ka siis, kui majapidamises ülejääke ei tekkinud ja müüdav osa võeti normaalse tarbimise arvelt. Vilja tuli väljast juurde muretseda (laenata või osta) raskematel ja korduvatel ikaldusaastatel, kui magasivarud ammendusid. Kuigi talurahvas kannatas leiva- ja seemneviljapuudust ka normaalse saagikusega aastatel 19. sajandi keskpaigani välja ning seetõttu oli üsna tavapärane taluperede igakevadine näljalünk, saadi sellest vallamagasitesse kogutud varude abil jagu. Keskmist saaki niisugustel aastatel hindavad tolleaegsed autorid üldiselt 5-6 seemnele rukkil, kaeral vähem. Halb saak tähendas 3-4 seemet (Sulev Vahtre, "Ilmastikuoludest Eestis XVIII ja XIX sajandil (kuni 1870. a.) ja nende mõjust põllumajandusele ning talurahva olukorrale", Tartu Riikliku Ülikooli Toimetised, 258 (Tartu, 1970), 147; Juhan Kahk, Murrangulised neljakümnendad (Tallinn: Eesti Raamat, 1978), 34). Vallamagasite tähtsus ajapikku küll vähenes, kuid ei kadunud sootuks. Veel 1892. aasta aruandes kirjutas Liivimaa kuberner, et käiku ei lastud "mitte ainult kõik magasivarud", vaid ka vallakassade toitluskapitalid, mis mõnes vallas kulutati vilja ostuks viimase kopikani (Ajalooarhiiv [edaspidi EAA], f. 296, n. 1, s. 81). Talud võisid vilja osta mitmesugustel põhjustel. Näiteks Viljandimaa ja Kagu-Pärnumaa taludes osteti juba enne 1840. aastaid vilja mõisast juurde, sest põllud külvati rahateenimise eesmärgil lina alla (Eesti majandusajalugu, 1, toim Hendrik Sepp, Otto Liiv, Juhan Vasar (Tartu: Akadeemiline Kooperatiiv, 1937), 399).

5 Nende suhteline kaitstus viljahindade tõusu eest, juhul kui nad oma töökoha säilitasid, ilmnes näljahädade ajal, mil peamiste kannatajatena märgitakse allikates vabadikke. 
vabadikud oma põllulapist elatuda ei suutnud ning ebakindlate sissetulekute tõttu sõltusid nad teistest enam hinnavõngetest. 1870.-80. aastatel mängisid põllumajandussaaduste (sh teravilja) hinnad olulist rolli talude ostu intensiivsuse kujundamisel, mis kinnitab teravilja tähtsust kaubaartiklina. ${ }^{6}$ Viljakaubanduses osalesid ka vallad, kes - sõltuvalt olukorrast - kas panid magasivilja ülejääke müüki või nälja-aastail muretsesid toiduja seemnevilja juurde.

Artikli sissejuhatavas osas antakse lühike ülevaade teravilja tootmisest Eestis. Teises osas püütakse välja selgitada nominaalsete hindade muutumine ajas ja hinnaerinevused Eesti maakondade vahel. Hinnaerinevuste püsimine või kahanemine võimaldab hinnata Eesti-sisese turu lõimituse ulatust, sest hindade ühtlustumine annab tunnistust turgude integreeritusest. ${ }^{7}$ Hindu lühiajalises perspektiivis kujundanud faktoritest on artikli tähelepanu keskmes saagikus ja ekspordihinnad, mis olid põhilised hinnamõjurid aasta piires. ${ }^{8}$ Kuni Riia ja Tallinna ühendamiseni ülevenemaalisse raudteevõrgustikku (vastavalt $1861 / 71^{9}$ ja 1870 ), mis võimaldas Balti sadamate kaudu turustada teravilja varasemaga võrreldes määratult rohkem, sõltus pakkumine siinsel viljaturul peamiselt külvipinna suurusest ja saagikusest. Suured kogused Leedu, Valgevene, Vene jt alade vilja olid tulvanud Riia sadama kaudu Euroopasse juba raudtee-eelsel ajastul, kuid see kaubaviljahoovus üksnes läbis Liivimaa kubermangu, haarates kaasa vaid väikese osa siinsest toodangust. ${ }^{10}$ Kohaliku vilja eksport 1870 . aastatest

6 Uurijad on näidanud teatavat seost Põhja-Eesti (Toomas Püvi, "Talude päriseksostmisest Eestimaa kubermangus 19. sajandi lõpus”, Eesti NSV Teaduste Akadeemia Toimetised, 1989, 1, 67-79 (74)) ja olulist seost Kuramaa puhul (Mikhail Kozin, Latȳshkaya derevniya v 50-70-e gody XIX veka (Riga: Zinatne, 1976), 229). Liivimaal oli tähtsaim müügiprodukt lina.

7 Turgude lõimumise uurimisest hindade põhjal vt David Jacks, Market integration in the North and Baltic Seas, 1500-180o, Working Paper, 55/oo) (London School of Economics, 2000), <http://eprints.lse.ac.uk/22383/1/wp55.pdf> (13.5.2012).

8 Boris Mironov, "Faktorȳ dinamiki khlebnȳkh cen v Évropeřskoı̆ Rossii v 1801-1914 gg. i kolichestvennaya ocenka ikh vliyaniya", Matematicheskie metodȳissledovaniyakh po social'no-ékonomicheskoŭ istorii (Moskva: Nauka, 1975), 180-219 (192-199). Saagikuse mõju kohta Euroopa mastaabis vt Karl Gunnar Persson, Grain markets in Europe, 1500-1900: integration and deregulation, Cambridge Studies in Modern Economic History, 7 (Cambridge: Cambridge University Press, 1999), 91.

9 1861. a valmis Riia-Daugavpilsi liin ja 10 aastat hiljem ühendati Riia Orjoli kaudu Tsaritsõniga (Volgograd).

10 1793-1842 Riia kaudu eksporditud viljast pärines keskmiselt 2,6\% Liivimaalt, $41 \%$ Kuramaalt ja üle 30\% Vene sisekubermangudest (Heinrihs Strods, Razvitie sel'skokhozyaistvennogo proizvodstva i torgovlya $v$ Latvii (2-ya polovina XVIII -I-ya polovina XIX vv. (Riga: LGU, 1985), 38). Tähelepanuväärne on Kura- ja Liivimaa omavaheline võrdlus, sest veel 1840. aastatel oli Kuramaal teravilja külvipind põhjapoolse naaber- 
alates küll kasvas, kuid kuni 19. sajandi lõpuni tarbiti valdav osa teraviljatoodangust jätkuvalt siseturul. ${ }^{11}$ Raudteed mööda saabunud odav Vene vili aga langetas siinseid viljahindu ja muutis need senisest enam sõltuvaks maailmaturuhindadest.

Artikli kolmandas osas on peatähelepanu küsimustel, miks turg ei suutnud Baltikumis näljahädasid märkimisväärselt leevendada ning kuidas suhtusid turu ja hindade võimalikku reguleerimisse rüütelkonnad ja riigivõim. Näljahädade puhul on üks keskseid küsimusi, kas turg toimib viljapuudust leevendavalt või suurendab seda. ${ }^{12}$ Baltikum kuulus vaadeldaval perioodil nende regioonide hulka, kus teravilja toodeti oluliselt rohkem, kui seda kohapeal toiduks tarbiti. Ometi kimbutasid Baltikumi talurahvast 1860. aastate lõpuni korduvad näljahädad. 1840. aastatel Euroopat tabanud "viimast näljakriisi" Preisimaa näite varal uurinud Hans H. Bass on rõhutanud, et transpordi arengu jt asjaolude tõttu polnud 19. sajandi keskpaigas toidupuudus mitte enam niivõrd looduslik nähtus, kuivõrd tulenes nappivatest sissetulekutest. ${ }^{13}$

Alljärgneva peamine eesmärk on juhtida tähelepanu meie ajalookirjutuses haigutavale tühimikule ning visandada rajajooned edasiseks uurimiseks, mis peaks hõlmama nii allikate ringi olulist avardamist kui ka hindu mõjutanud faktorite mitmekülgsemat analüüsi.

\section{Historiograafia ja allikad}

Eesti kesk- ja varauusaja viljahinnad ja -kaubandus on pälvinud laialdast tähelepanu, kuid 19. sajand on jäänud kummalisel kombel vaeslapse rolli.

provintsiga võrreldes kaks korda väiksem (Heinrihs Strods, Latvijas lauksaimniecības vēsture (Rīga: Zvaigzne, 1992), 130). Liivimaal läks ülejääkvili viinavabrikutesse. Seda, et väljast tulev vili oli transiitkaup ning mõjutas hindu vaid Riias, kinnitab ka Liivimaa kuberneri 1844. a aruanne, kus märgitakse küll suurt ikaldust kogu kubermangus, kuid siinsete elanike toitlustamiseks tarvitatud sisse toodud viljast ainult nisu. Samal ajal voolas Riia kaudu teistesse Vene riigi, aga eeskätt välismaa sadamatesse kokku sadu tuhandeid setverte erinevaid teravilju (Latvijas Vālsts vēstures arhīvs [edaspidi LVVA], 3. f., 10. apr., 2. 1., 29. lp.

11 Mikhail Kozin, "Vliyanie Russkogo khlebnogo eksporta na sel'skohozyaǔstvennoe proizvodstvo v Latvii (vtoroya polovina XIX v.)", Ékonomicheskie svyazi Pribaltiki s Rossiě (Riga: Zinatne, 1968), 208-225, siin 210; Ocherki ékonomicheskol̆ istorii Latvii (1860-1900), pod. red. M. I. Kozina (Riga: Zinatne, 1972), 217.

12 Mary E. Daly, "Something old and something new: recent research on the Great Irish Famine", When the potato failed: causes and effects of the last European subsistence crisis, 1845-1850, ed. by Cormac Ó Gráda, Richard Paping, and Eric Vanhaute (Turnhout: Brepols Publishers, 2007), 59-78 (60).

13 Hans H. Bass, "The crisis in Prussia", When the potato failed, 185-212 (193). 
Puuduvad uurimused viljahindade dünaamika kohta siseturul nii kogu sajandi jooksul kui ka üksikute ajalõikude kaupa. Meie teadmised viljahindade kohta on hoopis nigelamad kui näiteks talumaa hindade kohta, mida baltisaksa agraarstatistika erilise põhjalikkusega jälgis. Mõnevõrra rohkem on kirjutatud teravilja hindadest Lätis. Baltisaksa autorite sulest on ilmunud Riia börsihindadele tuginevaid statistilis-kirjeldavaid ülevaateid. ${ }^{14}$ Nõukogude ajal püüti üksikute arvude jadade esitamise kõrval hindade kujunemist mingil määral ka seletada ning teiste nähtustega seostada, ${ }^{15}$ kuid süstemaatiliste ja erinevaid tegureid hõlmavate analüüsideni ei jõutud ka siis. Hoopis teistsugune olukord valitseb aga vene ajalookirjutuses, kus teravilja hindu 19. sajandil kogu impeeriumi mastaabis on käsitlenud juhtivad agraarajaloolased nii eraldiseisva teemana süvitsi kui ka ühe aspektina ülevenemaalise turu tekkest. ${ }^{16}$

Põhiline osa artikli aluseks olevast lähteandmestikust saagikuse ja siseturuhindade kohta on ammutatud kuberneride iga-aastastest aruannetest pealinna. ${ }^{17}$ Neid aruandeid on kasutatud samade küsimuste valgustamisel ka vene ajalookirjutuses. ${ }^{18}$ Eesti- ja Liivimaal rajanesid aruanded 188 o. aastateni adra- resp. sillakohtunike ja raadide või linna politseivõimude, hiljem ka statistikakomitee saadetud teadetele saagikuse, külvipindade ja hindade kohta ning kohalikud kubermanguasutused lähtusid näljahädade ajal nii neist kui ka kihelkonnakohtute esitatud ülevaadetest vallamagasite seisu kohta leivaviljapuuduse väljaselgitamiseks ning näljaabi vajaduse kindlaksmääramiseks. Seetõttu ei saa need arvud olla päris valed. Proovirehtede

14 Nt Max von Blaese, Die Landwirtschaft in Kurland (Mitau: Steggenhagen, 1899), 60-64; Ernst Baron Campenhausen, "Ein Rückblick auf die Getreidepreise", Baltische Wochenschrift, 52 (1904), 495-500. Viimase andmed erinevad pisut Blaese omadest, sest keskmine hind on arvutatud erineva metoodikaga.

15 Strods, Lauksaimniecība Latvijä; Heinrihs Strods, "Die Preisbildung der landwirtschaftlichen Waren in Lettland Ende des 18. und Anfang des 19. Jahrhunderts", Acta Latgalica, 7 (Latgaḷu izdevnīceuba, 1981), 171-189; Kozin, "Vliyanie Russkogo khlebnogo eksporta", 208-225.

16 Boris Mironov, Khlebnye cenȳ v Rossii za dva stoletiya (XVIII-XIX vv.) (Leningrad: Nauka, 1985); vt ka historiograafia ülevaadet samas (lk 4-19); Ivan Kovalchenko, Leonid Milov, Vserossiiskǐ agrarnȳı̆ rȳnok XVIII-nachala XXv. Opȳt kolichestvennogo analiza (Moskva: Nauka, 1974).

${ }_{17}$ Eestis ja Lätis ei ole need kahjuks tervikuna säilinud. Kõiki aruandeid ja nende juurde kuuluvaid lisasid koondavad fondid Venemaa Riiklikus ajalooarhiivis (f. 1263 asuvad originaalid ja f. 1281 koopiad) ei olnud selle artikli autorile paraku kättesaadavad. Seepärast puuduvad andmed Eestimaa kubermangu hindade kohta 1841, 1843-45, 1858, 1868-69. Adrakohtunike arhiivide põllumajandusliku statistika osa on hävinud. 18 Mironov, "Faktorȳ dinamiki", 183, 193; Mironov, Khlebnȳe cenȳ; Ivan Kovalchenko, "Dinamika urovnya zemledel'cheskogo proizvodstva Rossii v pervoĭ polovine XIX v.", Istoriya SSSR, 1 (1959), 53-86. 
põhjal saadud andmed saagikuse kohta on usaldusväärsemad kui teated külvi(pinna) kogusuuruse või -saagi kohta. ${ }^{19}$ Baltikumis sai näljahädaoht mööda 1870. aastate alguseks, kuid Liivimaa toitluskomisjoni arhiivi on ladestunud linna- ja sillakohtute üksikasjalikud hinnateated 1880. aastate keskpaigani välja. Vene sisekubermangudes seevastu oli küsimus toiduviljapuudusest ja nälja vältimisest aktuaalne veel ka 20. sajandi alguses. ${ }^{20}$ Viljahinnad olid Venemaal nii riikliku kui ka ühiskondliku huvi keskmes. Need olid kogukonna kõrval kõige enam vaidlusi tekitanud küsimus Venemaa avalikkuses. ${ }^{21}$ Üle kogu impeeriumi olid erinevad politsei-, kohtu- või administratiivse järelevalve asutused kohustatud teostama seiret varude, saakide ja hindade üle, sest viljatoodangust ja/või -hindadest sõltusid riigi maksutulud, ${ }^{22}$ armee ülalpidamise kulud, aga ka näiteks massilise nälja ärahoidmine. 1860. aastatel sai hoo sisse riiklik statistiline arvestus.

Kuberneride aruandeid ja mitmeid keskasutustes valminud statistilisi kogumikke on vene ajaloolased hinnanud piisavalt usaldusväärseiks. Meil seisab viljahindade ja saagikuse kohta teadaolevate allikate läbitöötamine ning nende võrdlev kriitiline eritelu alles ees.

Põgusaimgi tutvus silla- resp. adrakohtunike teadetega manitseb ettevaatusele. Nimetatud ametnike töökohustuste ring oli äärmiselt lai ning ka statistilisi andmeid tuli neil edastada väga paljude valdkondade kohta, mistõttu ei ole üllatav, et näiteks hinnaandmed, mida oli ette nähtud saata suisa kahenädalaste intervallidega, kirjutati lihtsalt ühest aruandest teise

19 Andmed külvi hulga kohta erinevates allikates lahknevad. Nt Saaremaa sillakohtuniku teated toitluskomisjonile suvivilja ja kartuli külvi suuruse kohta 1875-81 on aasta-aastalt täpselt ühesugused, talivilja osas toimub minimaalseid muutusi (LVVA, 29. f., 1. apr., 232., 235., 240., 244. 1.). Seejuures on lahknevused kuberneri iga-aastastes raportides toodud arvudega väga tõsised (vrd EAA, f. 296, n. 5, s. 1283, 1988, 2766). Kuberneri aruannete järgi püsis rukki, odra ja kaera külvi suurus Tartumaal 1873-82 muutumatuna. Eestimaa kuberneri aruannete lisades on külvi hulgad enamasti väiksemad kui statistilistes kogumikes (vrd nt Obzor Éstlyandskoй gubernii za 1890 goda (Revel, 1891); Urozhai 1890 goda v Evropeiskoŭ i Aziatskoŭ Rossii (S.-Peterburg, 1891). Saagikus seevastu erineb mõlemas allikas üsna vähe (nt rukki puhul vastavalt 5,8 ja 5,7 seemet, kaeral 4,9 ja 5,1 seemet, odral 6 ja 5,8 seemet). Ka viljahinnad erinesid allikates: nii olid Liivimaa toitluskomisjoni käsutusse laekunud andmetel hinnad 1868 märksa kõrgemad kui kuberneri aastaaruandes.

20 Vt nt A. S. Ermolov, Nashi neurozhai i prodovol'stvennȳĭ vopros, 1-2 (S.-Peterburg, 1909).

21 Mironov, Khlebnȳe cenȳ, 13.

22 1840. aastatel tõusis vili Vene väljaveos esikohale (Strods, Razvitie, 58). Sajandi lõpuks kasvas viljaeksport tohutult ja seda paljuski tarbimise arvelt, sest taludel tuli vilja müüa maksude ning üle jõu käivate väljaostumaksude õiendamiseks (Mironov, "Faktorȳ dinamiki", 197; Ocherki, 215; Richard Robbins, Famine in Russia, 1891-1892: the imperial government responds to a crisis (New York: Columbia University Press, 1975), 7). 
ümber. Sel põhjusel jäävad analüüsist kõrvale Viljandi sillakohtuniku teated viljahindade kohta aastatest 1851-6o, sest need püsisid läbi kogu selle perioodi üsna ühtlasena, sõltumata saagikusest või aastaajast. ${ }^{23}$ Ühe näite põhjal ei saa aga teha järeldusi teiste silla- ja adrakohtunike esitatud andmete kohta ning tunnistada need mitteusaldusväärseiks. Erinevate ametnike eksimused on üksteisest sõltumatud, mistõttu vead ei kumuleeru. Arvude jadad peegeldavad suundumusi adekvaatselt. ${ }^{24}$

Hinnaandmete tõepära saab hinnata ka arvude omavahelise kooskõlalisuse ja liikumise loogilisuse põhjal (nt kas nad liiguvad maakondades samas suunas või reageerivad saagikuse muutustele). Liivimaa 1845 . aasta andmete adekvaatsus selgub kõrvutamisel selle hinnaga, millega toitluskomisjoni käsul riikliku toetuslaenu eest näljahädalistele vilja kohtadel kokku osteti. Komisjon maksis setverti rukki eest kuni 7,5 rubla (vrd lisa 2). ${ }^{25}$ Kuberneride iga-aastaste aruannete lisad sisaldavad teraviljahindu maakondade kaupa 1869. aastani. Liivimaa toitluskomisjoni arhiiv võimaldab Liivimaa Eesti osa hindu jälgida 1884. aastani. ${ }^{26} 1875 .-98$. aastate hinnad pärinevad statistilistest kogumikest. ${ }^{27}$ Sel ajal olid maakondlikud hinnaerinevused tagasihoidlikumad (lisa 1) ja nende seos saagikusega väike.

\section{Teraviljade külvipind ja saagikus}

Läbi kogu 19. sajandi kuulus Eestis külvipinnast üle poole taludele, kuid mõisate ja talude suhtelises osakaalus toimusid selle aja sees märkimisväärsed nihked: kui mõisastamine ja kvoodi-/kuuendikumaade eraldamine vähendasid talumaid sajandi viimase veerandini, siis sajandi viimastel kümnenditel toimus pööre vastassuunas ning talude külvipinna suhteline osatähtsus hakkas kasvama. ${ }^{28}$ 1840. aastatel valitses nii mõisa- kui

\footnotetext{
23 "Muutumatud" on hinnad ka 1881-84 ja Võrumaal 1880-87 (lisad 2 ja 4).

24 Usaldusväärsuse kohta vt Juhan Kahk, "Die Getreide- und Kartoffelproduktion in Estland im 19. Jahrhundert im Spiegel der Gouverneursberichte. Gedanken über die Parallelentwicklung von Guts- und Bauernwirtschaften im Baltikum", Eesti TA Toimetised, Humanitaar- ja Sotsiaalteadused, 1 (1993), 9-10; Kahk, Die Krise, 239-243; Mironov, Khlebnȳe cenȳ, 31.

25 Setvert rukist $=3$ vakka $=360$ naela $=147 \mathrm{~kg}$; setvert otri $=300$ naela $=123 \mathrm{~kg}$. Rukki setvert $=9$ puuda.

26 Erinevalt Liivimaast Eestimaal 1820. aastatel loodud toitluskomisjon kaua tegutseda ei saanud ja saadeti peagi laiali. 186o. aastate lõpu näljahäda ajal korraldas seal näljaabi ajutine toitluskomisjon käsikäes rüütelkonna ja hädaabikomiteega.

27 Vt viited lisades.

28 Strods, Lauksaimniecība Latvijā, 98; Heinrihs Strods, "Sborȳi urozhainost' khlebov v Latvii v 8o-kh godakh XVIII - nachale 6o-kh godov XIX v.", Ezhegodnik po agrarno istorii Vostochnoŭ Évropȳ (Minsk, 1964), 330-340 (334); Posevnȳya ploshchadi, Vremen-
} 
talupõldudel kolmeväljasüsteem, mis tähendas, et kuni 40 protsendil külvipinnast kasvatati talirukist, teisel väljal suvivilja ning kolmas oli kesas. ${ }^{29}$ Rukis oli valdava osa elanikkonna peatoidus ning väga oluline kaubaartikkel rahvusvahelisel turul. Oder oli nii toidu- kui ka õllevili. Kaera kasvatati peamiselt loomasöödaks. Rukis ja oder domineerisid nii mõisa- kui ka talupõldudel 19. sajandi viimase veerandini, Lõuna-Eestis vahetasid oder ja kaer kohad juba hiljemalt 1870. aastateks ning Põhja-Eestis 1880. aastatel, kuid Saaremaal jäi kaer vähemtähtsaks põllukultuuriks 19. sajandi lõpuni. ${ }^{30}$ Külvipinna struktuuri olulisi muutusi toonud üleminek viljavaheldussüsteemile, mis andis järjest enam ruumi söödakultuuridele, ei vääranud algul rukki esikohta põllukultuuride vahekorras. Rukki juhtpositsiooni kõigutas alles viljahindade langus 188o. aastatel. Liivimaal kadusid olulised erinevused rukki, kaera ja odra külvipindade suuruses sajandi lõpuks: kaera külvipind (22,9\% kogu külvipinnast) ületas ainult pisut talirukki $(21,4 \%)$ ja odra $(19,1 \%)$ oma. ${ }^{31} 1840$. aastatel Baltikumis laiemalt levima hakanud kartulikasvatuse hoogsamat arengut pärssisid kümnendi teisel poolel ja järgmise algul taimehaigused. Kartuli külvipind suurenes plahvatuslikult sajandi viimasel kolmandikul, ${ }^{32}$ seda eriti väheviljakate põllumaadega Põhja-Eestis, hõivates seal sajandivahetusel tublisti üle kümnendiku kogu külvipinnast. ${ }^{33}$ Põhiline osa saagist voolas viinavabrikutesse. ${ }^{34}$

Võrreldes 1840.-50. aastatega kasvasid külvipind ja saagikus sajandi lõpuks nii mõisa- kui talumajapidamistes. ${ }^{35}$ Külvipind suurenes tänu uudismaade ülesharimisele ja kesa osakaalu märgatavale kahanemisele seoses üleminekuga viljavaheldussüsteemile. Üldine külvipinna laienemine

nik Central'nogo Statisticheskogo Komiteta, 48 (S.-Peterburg, 1901), 23, 51; kuberneride aastaaruanded. Siiski selgub Eestimaa kuberneri aruannetest, et sajandi keskel oli aastaid, mil suvivilja külvati mõisates rohkem kui taludes (nt 1847, 1853, EAA, f. 291, n. 1, S. 13383; 11029).

29 Kahk, Die Krise, 48

30 Kuberneride aruanded (EAA, f. 29, 291 ja 296); Obzorȳ Éstlyandskǒ̆ gubernii za 1885-1900 gg. (Reval, 1886-1901).

31 Kozin, "Vliyanie", 223. Maakonna politseivalitsuste ja vallavalitsuste kaudu kogutud andmetel olid aga vahed suuremad: talirukist kasvatati 172 702, kaera 181010 ja otri 155397 tiinul (Posevnȳya ploshchadi, 23).

32 LVVA, 1. f., 4. apr., 1763. 1., 34.-35. lp., Eestimaa kuberner Balti kindralkubernerile 28.10.1849; ibid., 320. 1, 1. 55, Liivimaa kuberneri 1851. aasta aruanne. Kartuli külvi hulka Liivimaal 1843-1852 vt Strods, Lauksaimniecība Latvijā, 120, ja külvi hulka kogu Eestis 1842-1900 vt Kahk, “Die Getreide- und Kartoffelproduktion”, 12.

33 Eesti ajalugu, V, toim Toomas Karjahärm ja Tiit Rosenberg (Tartu: Ilmamaa, 2011), 115.

34 Eestis õpiti kartulist viina valmistama 1830. aastatel. Kartul oli viina toormena teraviljast odavam (Kahk, Die Krise, 67-70), vt nt Obzor Éstlyandskoŭ gubernii za 1885 g., 16.

35 Kahk, "Die Getreide- und Kartoffelproduktion", 18-19. 
ei toonud kaasa olulisi muutusi talirukki külvis, see püsis sarnasel tasemel kogu sajandi vältel. ${ }^{36}$ Sajandi teisel poolel laienes aga järsult kaerakasvatus. Kolmest põhilisest teraviljaliigist oli kõrgeima keskmise saagikusega rukis ja madalaimaga kaer. Talirukis oli suhteliselt ilmastikukindel, talus rahuldavalt ebasoodsaid kasvutingimusi ning andis korralikul väetamisel odrast palju paremat saaki. Kaera madalam saagikus seletub muuhulgas asjaoluga, et seda külvati halvematele maadele, mis rukki ja odra jaoks vähem sobisid. Põlluviljakus oli väga kõikuv ning erinevates valdades või isegi külades võis saagikus oluliselt erineda. Tunduvad erinevused joonistuvad välja maakondade vahel (lisad 2 ja 4). Eestimaa jäi saagikuse kasvult Liivimaast maha. Klimaatilised tingimused ja mullastik mõjutasid saagikust ning seeläbi omakorda viljahindu. Samuti oli Põhja-Eesti põllumajanduse kapitalistlik areng võrreldes Lõuna-Eestiga peetunum.

Kogu 19. sajandi vältel on jälgitavad vahed mõisa- ja talupõldude saagikuses. ${ }^{37}$ Hiljutises Eesti ajaloo koguteoses on hinnatud mõisapõldude saagikust sajandi lõpupoole 5-10 protsenti kõrgemaks talupõldude omast, ${ }^{38}$ ehkki varasemas kirjanduses ja allikates võib leida ka hoopis suuremaid erinevusi. ${ }^{39}$ Põlluviljakuse kiiremat tõusu mõisamajandites on seletatud parema väetamise ja agrotehnika rakendamisega (külvi- ja rehepeksumasinad, tõhusamad künniriistad, paremad viljasordid jm).

Majandusanalüüsis eristatakse hinna lühiajalist ehk turgu korrastavat ja pikaajalist ehk juhtivat (ümberpaigutavat) funktsiooni. Viimane tähendab muuhulgas ressursside ümberpaigutamist uutesse tasuvamatesse tootmisvaldkondadesse ja see avaldub üsna selgelt kogu Baltikumi põllumajanduses. Konjunktuurimuutused agraarsaaduste turul mõjutasid tootmise arengusuundi ja uuenduste läbiviimist mõisamajanduses ning mõningase ajalise nihkega ka taludes. Vaadeldava perioodi algul said mõisad põhilise osa sissetulekutest viljast ja viinapõletamisest või nendega seotud majandusharudest. Valdava osa mõisate teraviljasaagist neelas viinapõletus ja nuumhärgade toitmine. ${ }^{40}$ Siseturul vajasid suurtes kogustes vilja riik sõjaväe

\footnotetext{
36 Kahk, "Die Getreide- und Kartoffelproduktion", 11.

37 Vahtre, "Ilmastikuoludest Eestis", 106; Kahk, Die Krise, 204; EAA, f. 29, 291 ja 296, kuberneride aruanded.

38 Eesti ajalugu, V, 115.

39 EAA, f. 29, 291 ja 296, kuberneride aruanded; Juhan Kahk, "Uue põllumajanduse algus Eestis", Eesti TA Toimetised, 1 (1994), 116-117; Ocherki, 229. Lõuna-Liivimaa kohta vt Lida Balevica, "Adelsgüter und Bauernwirtschaften in Südlivland und die Rolle der Livländischen Adeligen Gütercreditsozietät 1880-1905", Bevölkerungsverschiebungen und sozialer Wandel in den baltischen Provinzen 1850-1914, hrsg. von Gert von Pistohlkors (Lüneburg: Institut Nordostdeutsches Kulturwerk, 1985), 113.

40 Kahk, Die Krise, 114
} 
toidumoona ja furaažiga varustamiseks ${ }^{41}$ ning kasvavad linnad. Teravilja ja viina hinna muutumine sundisid üht osa mõisnikke viinatootmist kaasajastama, suurendama ja kontsentreerima, aga enamikku ümber orienteeruma karjamajandusele. Piimakarjandusele hakkasid sajandi viimasel veerandil rõhku panema ka talud.

\section{Rukki ja kaera hinnad}

Teravilja hindu mõjutanud tegurid võib jagada kolmeks: lühiajalised (juhuslikud), tsüklilised ja pikaajalised. Hindu mõjutasid nii eraldi kui ka omavahelises koostoimes külvipind ja saagikus; tootmiskulud; pakkumine ja nõudlus, mis hõlmas talurahva, põllumajanduses mittehõivatud elanikkonna, sõjaväe ja tööstuse (nt viinavabrikute) nõudluse; loomakasvatuse tase; välisturgude olukord; transaktsioonikulud, ringluses olnud raha hulk jm. ${ }^{42}$ Enamik neist ei leia siinkohal käsitlemist (mis ei tähenda, et nad polnud olulised või ei vääriks eritlemist). Loetletud teguritest vaadeldakse kahte - saagikust ja ekspordihindu, mille puhul on seosed statistilise andmeanalüüsi meetoditega hõlpsasti tuvastatavad.

Rukki ja kaera keskmine nominaalhind kasvas iga kümnendiga kuni 1890. aastateni (lisad 2-4). Hindade jälgimisel on oluline aga eristada nominaal- ja reaalhindade dünaamikat. Rubla aeglane, kuid pidev devalveerumine ${ }^{43}$ kahandas hinnatõusu soodustavat mõju põllumajandusele. Hindade muutumine teraviljaliikide kaupa reaalhindades on toodud Boris Mironovil, kelle järgi Baltikumis rukki reaalhind tõusis 1840. ja 50. aastatel, langes pisut 1860. aastatel, saavutas 1870. aastatel oma kõrgpunkti ega tõusnud sajandi lópuks keskmiselt isegi mitte 1840 . aastate tasemele. ${ }^{44}$ Kaera hind tegi läbi sarnase arengu, kuid 1880. aastatel ei olnud langus nii järsk ja hind jäi kõrgemaks 1840. aastate tasemest.

Kaera hind kõikus kohalikel turgudel keskmiselt sama palju kui rukki oma. 1840-84 erinesid rukki setverti madalaim ja kõrgeim hind Tartumaal 3,2; Võrumaal 3,1; Viljandimaal 3,8; Pärnumaal 3,4 ja Saaremaal 3,3 korda (lisa 2). Kaera puhul oli kõnealune vahe 3,3 Tartu-, 3,5 Võru-, 3,2 Viljandi-, 3,6 Pärnu- ja 3,2 korda Saaremaal. Riia börsil kõikus samal ajal rukki hind

${ }_{41}$ Sõjaväele müüdud vilja hulk on nii eesti kui läti ajalookirjutuses täiesti uurimata teema. Kuberneride aruannetest võib leida viiteid, et vilja kokkuost siin paiknenud ulatusliku sõjaväekontingendi tarbeks aitas tõsta kohalikke hindu (vt nt EAA, f. 29, n. 3, s. 874, 1. 2op, Eestimaa kuberneri 1848. aasta aruanne).

42 Mironov, "Faktorȳ dinamiki", 181.

43 Mironov, Khlebnȳe ceñ̄, 39.

${ }_{44}$ Keskmised hinnad on arvutatud kümnendite kaupa (Mironov, Khlebnȳe cenȳ, 68-69). 
3,4 ja kaera oma 2,7 korda. Börsil lähenes kaera hind puudades jõudsalt rukki omale, moodustades sõltuvalt kümnendist 79,4-93,6 protsenti rukki hinnast. ${ }^{45}$ Väike tagasilöök tuli 1860. aastatel ja sarnane muutus nähtub ka maakondlikest aegridadest. Lõuna-Eesti maakondades ja Saaremaal moodustas kaera setvert 1840.-84. aastatel 52-73 protsenti rukki setverti hinnast, olles suurim 1850. aastatel. Mahuühikutes (setvertides) ei jõudnud kaera hind rukki omale järele, kuid massiühikutes (puudades) olid nende hinnad väga sarnased ka siseturul. ${ }^{46}$ Kaera kallinemist rukki suhtes on seletatud karjamajanduse osatähtsuse tõusuga ja toidulaua mitmekesistumisega, mis olid üleeuroopalised protsessid.

Turgude integreeritusest annavad tunnistust hinnataseme ja -dünaamika omavaheline seotus eri regioonides. Neist esimest mõõdame variatsioonikoefitsiendi ja teist korrelatsioonianalüüsi abil. Rukki ja kaera hinna variatsioonikoefitsient ajaga oluliselt ei muutunud. See vähenes Liivi- ja Kuramaal ränga ikalduse aastail (1867-68), st nälg mõjus hindu ühtlustavalt, kuid järgnev hinna langus kulges teistest kiiremini Pärnu ja Riia maakonnas. Lõuna-Eesti hindade tase ei erinenud oluliselt Põhja-Eesti omast, v.a 1840. aastatel ja 186o. aastate esimesel poolel, pigem olid lahknevused maakondade vahel. Tuntavad regionaalsed erinevused rukki hindades Eesti alal jäid püsima ka 20. sajandi esimesel kümnendil. ${ }^{47}$ Hinnataset kergitasid nii parem elujärg (nt Viljandimaal) kui ka kaugus suurematest linnadest. Aastatel 1875-87 olid hinnad keskmisest kõrgemad Lääne-, Võru- ja Saaremaal, mis asusid kaubandussõlmedest eemal (vt lisa 1).

Turud on integreerunud, kui hinnad liiguvad erinevatel turgudel sünkroonselt. Kuna ilmastikuolud ja saagikus mõjutavad hindu samal määral samas suunas, ei näita ainuüksi sünkroonsus tegelikku turgude lõimitust, kuid saagikuse mõju hindadele vähenes juba 1850. aastatest. 1875.-86. aastal oli Eesti- ja Liivimaa rukki hindade vaheline korrelatsioonikordaja $r=0,87$ ja determinatsioonikordaja $r^{2}=0,76$ ehk siis mõlemas kubermangus olid hinnad 76 protsendi ulatuses determineeritud üldiste faktorite poolt. Kaera hindade vahel oli $r=0,8$. Lõuna-Eesti maakondade rukki hindade vahel (v.a Viljandimaa) oli 1841.-84. aastal $r=0,84$ ja $r=0,88$ vahel. Kaeral jäi $r=0,75$ ja $r=0,89$ vahele.

Rukki ja kaera hinnad kõikusid aastatel 1840-1900 tsükliliselt. Tsükli üldisest pildist eristuvad nälja-aastad. Teravilja hindade tõus, mis väikeste

45 Blaese, Die Landwirtschaft, 64.

46 EAA, f. 191, n. 1, s. 4 ja 6; f. 56, n. 1, s. 435, 438, 444-445, 448, 450-452.

47 Järva- ja Virumaa näitel vt: EAA, f. 56, n. 1, s. 451, 452, 455, 458, 460, 462, 465, 466, $469,471,473,475,476$; f. 61, n. 1, s. 500-505. 
tagasilöökidega oli kestnud 18. sajandi keskpaigast, sai läbi 1820. aastatel, mil algas kaks aastakümmet väldanud langus. Riias langes rukki hind pea kaks korda ${ }^{48}{ }^{1845} \cdot-47$. aastad lópetasid enam kui 25 -aastase madalate hindade perioodi Euroopas ja algas sama pikk kõrgete hindade tsükkel. ${ }^{49}$ Liivimaal kukkusid 1844.-46. aasta näljakriisi lõppedes viljahinnad näljaajaga võrreldes kuni poole võrra. ${ }^{50}$ Eestimaa hinnad 1840. aastate keskel ja lõpus samavõrd drastilisi võnkeid läbi ei teinud. Praegune uurimisseis ei võimalda öelda, kas kriisi väiksem teravus kajastub ka demograafilises andmestikus, kuid nii saagikuse kui ka Eestimaale eraldatud riikliku toetuslaenu mahu järgi võib oletada, et Eesti põhjaosa kannatas vähem..${ }^{51}$ Seda räägivad ka viljahinnad. Eesti alal tervikuna algas hindade kõrgperiood 1853. aastast. 1853.-56. aastal olid hinnad kõrged kogu Euroopas. ${ }^{52}$ Teraviljahindade järjekordne langus algas siin Euroopaga võrreldes mõningase hilinemisega, 1880. aastate keskpaigas, ning asendus 189o. aastate lõpus uue tõusuga. Siinset suhteliselt kõrget hinnataset 1880. aastate esimese poolel on seletatud mitmeid Venemaa kubermange tabanud viljaikaldustega. ${ }^{53}$ Sellesse üldise viljahindade madalseisu aega mahuvad kaks aastat (1891 ja 1892), mil Venemaa näljakriisi ja Euroopa suurenenud nõudluse tõttu kerkisid Baltikumis hinnad tavapärasest oluliselt kõrgemale.

Viljahindade tsüklilisus kohalikel turgudel tõendab kohalike hindade seotust hinnakonjunktuuriga Euroopa ja Venemaa turgudel, kus 19. sajandil liikusid hinnad üldiselt sünkroonselt ja hinnataseme erinevused vähenesid sajandi lõpuks 20-30 protsendini. ${ }^{54}$ Juba 17. sajandil oli Baltikumi

48 Strods, Razvitie, 9-11.

49 Bass, "The crisis in Prussia", 192.

50 Kuberneri aruannete järgi oli langus kohalikel turgudel väiksem (lisa 2), kuid Balti kindralkuberneri kirjavahetuses võib leida ka teistsuguseid andmeid. Liivimaa Riigivarade Valitsuse ülem kirjutas kindralkubernerile 19.12.1849, et rukki setverti hind olevat "kusagil kolmandik 1845-46 hinnatasemest" (EAA, f. 2054, n. 1, s. 1199) ja Liivimaa toitluskomisjon osutas börsihindadele tuginedes rukkihindade langemisele 40\% võrra (kindralkubernerile 5.1.1849: ibid.). Riia börsi hinnad kukkusid poole võrra (Blaese, Die Landwirtschaft, 6o-64). Sarnase järsu languse tegi rukki hind läbi ka nt Saksi- ja Preisimaal (Bass, "The crisis in Prussia”, 197-198).

${ }_{51}$ Kokku küündis rahas ja viljas Liivimaale antud riikliku toetuslaenu väärtus üle miljoni rubla (EAA, f. 2054, n. 1, s. 1200, Liivimaa toitluskomisjon kindralkubernerile, septembris 1856). Kuramaale eraldati 1845-47 u pool miljonit rubla (Strods, Lauksaimniecïba Latvijä, 364); Eestimaa sai kordades vähem raha (EAA, f. 2054, n. 1, s. 1200).

52 Peter M. Solar, "The crisis of the late 1840 s: what can be learned from prices?", When the potato failed, 79-91 (91).

53 Püvi, "Talude päriseksostmisest", 69.

54 Boris Mironov, "Wages and prices in Imperial Russia, 1703-1913 ", Russian Review, 49 (January 2010), 47-72 (58). 
sadamalinnades teravilja hind seotud hinnakonjunktuuriga välisturgudel. ${ }^{55}$ Baltikumi sadamates olid 18.-19. sajandil viljahinnad ühed kõrgemad Vene riigis, mistõttu transpordivõimaluste paranedes hinnaerinevused Vene viljaga paratamatult kahanesid. ${ }^{56}$

Kas ja kuivõrd seostusid hinnad Eesti ala maakondades hindadega sadamates ja maailmaturul? Juhan Kahk on analüüsinud linnade omavahelist ning linnade ja maaturu vahelist hindade korrelatsiooni 1843. aastal ning jõudnud järeldusele, et ühe aasta piires polnud olulist korrelatsiooni ja maaturu hinnad ei sõltunud maailmaturu hindadest. ${ }^{57}$ Maakonnalinnade hinnad liikusid hilinemisega Riia hindade järel ja mitte ülearu täpselt; kaugemate paikade hinnad olid 19. sajandi keskpaigani küllaltki iseseisvad. ${ }^{58}$

Hoopis teistsugune pilt avaneb vaadates pikki ajaperioode. Aastatel 1840-84 olid vilja hinnad Riia börsil ja maakondades tugevas korrelatsioonis. Rukki puhul oli Riia börsihindade ja maakondlike hindade korrelatsioonikordaja Tartumaaga $r=0,82$, Võrumaaga $r=0,76,{ }^{59}$ Pärnumaaga $r=0,8$ ja Saaremaaga $r=0,87$. Kaera puhul olid vastavad kordajad o,71; o,8; 0,87 ja 0,83. 1862-69 ületasid Liivimaal kohalikud hinnad väljaveohindu keskmiselt 27,2 protsenti. Välja veeti põhiliselt mujalt siia kokku veetud vilja. Raudtee-ajastul sõltusid kohaliku turu hinnad mitte ülejääkidest, nõudlusest ega pakkumisest, vaid ekspordihindadest, mis omakorda sõltusid maailmaturuhindadest ja sisseveost Venemaalt. ${ }^{60}$

Püsiva nõudluse ja tagavarade vähesuse tingimustes sõltusid viljahinnad saagikusest. Külvipinna kiire kasv vähendas seda mõju. ${ }^{61}$ Kuberneri aruannetes seostati aga 1840 . aastatel ja 1850. aastate algul hindu saagikusega. ${ }^{62}$ Rukki hinnal oli keskmisest tugevam kahanev korrelatsioon saagikusega

\footnotetext{
55 Arnold Soom, Der baltische Getreidehandel im 17. Jahrhundert (Stockholm: Almqvist \& Wiksell, 1961); Strods, Razvitie, 12, 24.

56 Strods, Razvitie, 57.

57 Kahk, Die Krise, 96-98.

58 Selline analüüs eeldab igakuiste hindade väljaselgitamist, mida siinse artikli raames pole selle liigse töömahukuse tõttu ette võetud. Uurida tuleks, kui kiiresti taastus tavapärane hinnasuhe erinevatel turgudel pärast järske muutusi nõudluse ja pakkumise vahekorras (Persson, Grain markets, 92-96).

59 See võib seletuda hinnaandmete vähesema täpsusega. Kuna 1880.-84. a hinnad ei muutunud, siis jäid need analüüsist kõrvale. Nähtavasti olid need ümber kirjutatud varasematest aruannetest.

60 Ocherki, 217

${ }_{61}$ Mironov, "Faktorȳ dinamiki", 192.

62 EAA, f. 29, n. 1, s. 4527; 4531; LVVA, 1. f., 4. apr., 319., 321 lp.
} 
1841.-52. aastal ${ }^{63}$ Tartu- ja Pärnumaal (vastavalt $r=-0,68$ ja $\left.r=-0,64\right),{ }^{64}$ kuid samasugune seos ei ilmne teistes maakondades. Saagikuse ja hinna seose väljaselgitamiseks Põhja-Eestis oleks vaja teada saagikust maakondade kaupa, kuid kuberneride aruannetest see ei selgu. Hilisematel kümnenditel tundub sõltumus saagikusest kaduvat, v.a nälja-aastail. Näiteks Põhja-Eestis jäi 189o-91 rukki saagikus peaaegu samaks, ent hind kahekordistus, ${ }^{65}$ mis näitab hinna sõltumist suurimal määral hoopis Vene sisseveost.

\section{Viljahinnad nälja-aastail}

Enamik näljahädasid on põhjustatud mitme teguri omavahelisest kombinatsioonist nagu saakide äpardumine, turgude ebapiisav toimimine ja ühiskonnagruppide erinevad õigused (entitlement) toidule.

1840. aastate kriisi ajal järgnes üksteisele mitu ikaldusaastat (lisad 2 ja 3). Kogu Eestis (v.a Saaremaal) olid saagid nigelad juba 1843. aastal. 1844. aasta saagi Liivimaal hävitasid eeskätt jaanipäevast septembrini kestnud vihmad ning tormid. Lakkamatu vihma käes mädanesid vili ja hein ning saak ikaldus täielikult. 1845. aastal äpardus rukis üle Eesti. Niisamuti hävitas põud suvivilja. Teravilja saagikust hinnati 1845 . aastal Liivimaa kubermangu Eesti osa talupõldudel keskmiselt 1,9 seemnele ${ }^{66}$ ehk ligikaudu pooleni tavapärasest. Selline vähenemine oli 19. sajandi oludes äärmuslik. Eestimaa kubermangus saagikus nii drastiliselt ei langenud. Ka 1868. aastal ei olnud Põhja-Eestis põllusaak tavalisest päris poole väiksem, ${ }^{67}$ küll aga oli see nii Liivimaa kõige enam kannatanud maakonnas, Saaremaal, kus suvivilja lõigati pool tavapärasest ja talivilja veel vähem. Vili oli seal osaliselt ikaldunud juba 1867. aasta vihmasel suvel.

"Näljastel neljakümnendatel" tõusid viljahinnad Baltikumis ennekuulmatult kõrgele. ${ }^{68}$ Sama kordus 1868. aastal. Üldiselt on täheldatud, et ikal-

\footnotetext{
63 Korrelatsiooniks sobilike ajavahemike valimise kohta vt Boris Mironov, "O metodike obrabotki istochnikov po istorii cen”, Arheograficheskǐ ezhegodnik za 1968 g. (Moskva, 1970), 154-165.

64 Korrelatsioon saagikuse ja järgmise aasta $(n+1)$ hinna vahel on märksa väiksem, vastavalt $r=-0,45 \mathrm{ja}-0,54$.

65 1890. a oli Eestimaa kubermangus keskmine rukki saagikus 5,8 seemet ja setvert maksis 7,3 rubla, 1891. aastal olid vastavad arvud 5,7 seemet ja 11,68 rubla (Obzor $\bar{y}$ Éstlyandskoĭ gubernii za 1890-1891 gg.).

66 Kahk, Die Krise, 246.

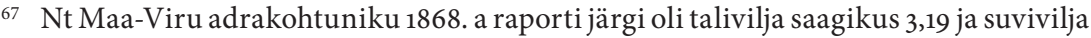
saagikus 2,36 seemet, kartulil 2,76 (EAA, f. 902, n. 1, s. 1137).

68 Hinnad tõusid suhteliselt rohkem linnades, kus nad olid olnud madalamad kui maal (EAA, f. 296, n. 4, s. 1408, 1. 26, 36-37, 52).
} 
duste korral on hinnareaktsioon saagikuse muutusest suhteliselt tugevam, ${ }^{69}$ sest nõudmine peatoidusele on hinna suhtes väheelastne. Hinnareaktsioon Baltikumis varieerus piirkonniti. Saagikuse langus poole võrra tõi kaasa hindade kahekordistumise näiteks Lõuna-Eestis ja Kuramaal 1845. aastal ${ }^{70}$ ning Saaremaal 1868. aastal. Eestimaal maksis 1853.-66. aastal rukkisetvert keskmiselt 6,75 rubla, 1868 . aasta sügisel müüdi seda 10,5 rubla eest. ${ }^{71}$ Erinev oli olukord Liivimaa kubermangus, kus rukki saagikus võrreldes 1862.-66. aastaga langes 1868 . aastal keskmiselt vähem ( 5,5 seemnelt neljale ehk $27 \%$ ) kui tõusis hind (setverti hind maal keskmiselt 7,84 rublalt 15 rublale ehk 91\%). ${ }^{72}$ Odra setverti hind kasvas samal ajal 6,5 rublalt 11,6 rublale (78\%). ${ }^{73}$ Asenduskaubana tuli 186o. aastatel kõne alla eeskätt kartul, kuid ka see ikaldus (1868. aastal saadi Liivimaal keskmiselt 3,7 seemet, sh Saaremaal kõigest pool seemet; Eestimaal kaks seemet ${ }^{74}$ ). Rukki kui peatoiduse 50-100-protsendilise hinnatõusu Eesti alal 1868. aastal tegi võimalikuks odra ja kartuli saagi äpardumine.

Viljahindu mõjutas varude olemasolu. Mõlema ülalkirjeldatud näljahäda ajal lõppes Liivimaa magasiaitades ja toitluskomisjonil varuvili enne, kui kriis jõudis haripunkti. Sama juhtus 1868. aastal Saaremaa talurahvapanga ja valdade varudega. Üks ikaldusaasta või ainult ühe toiduvilja saagi äpardumine enamasti hindu üles ei löönud.

Nii 1840. kui ka 1860. aastatel tähendas näljahäda tõsist demograafilist tagasilööki. ${ }^{75}$ Balti historiograafias on tihti viidatud haigustele, mis olevat külvanud surma, samal ajal kui näljasurmajuhtumid olnud väga harvad. Seejuures ei tohi aga unustada asjaolu, et mõned nakkushaigused, nagu kõhutüüfus ja düsenteeria, kaasnevad tüüpiliselt just näljaga. ${ }^{76} 1845$-46.

\footnotetext{
69 Bass, "The crisis in Prussia”, 192.

70 Rukki setvert maksis tavapärase 4,63 rubla asemel 8,89 rubla ja odrasetvert 3,37 rubla asemel 6,33 rubla (Kuramaa kuberneri 1845. a aruanne: LVVA, 1. f., 4. apr., 316. 1., 113.-190. lp.).

${ }_{71}$ EAA, f. 29, n. 2, s. 4759, Eestimaa toitluskomisjoni protokoll 3.1.1869. Maakonnakeskustes kehtinud hinnad lubavad aga oletada veelgi suuremat hinnatõusu: 1868. a oktoobris maksis rukkisetvert Tallinnas 11,34; Rakveres 12; Paides 12 ja Haapsalus 12,5 rubla (ibid., s. 7).

72 LVVA, 1. f., 4. apr., 1766., 1767., 1769. 1.; 3. f., 1. apr., 12815. 1., 134.-145. lp., Liivimaa toitluskomisjoni žurnaalid 1863-69.

${ }^{73} 1868$ oli suvivilja (odra kohta eraldi andmeid ei kogutud) saagikus kubermangus keskmiselt 2,7 seemet.

74 1867. a andmed (EAA, f. 29, n. 2, s. 4742); 1868. a võis see olla veelgi madalam.

75 1869. a ületas Eestimaal suremus sündivuse 5314 võrra (EAA, f. 29, n. 2, s. 4759). Liigsuremus (tavalisest kõrgem suremus) omandas erilise ulatuse Saaremaal.

76 Eric Vanhaute, Richard Paping, Cormac Ó Gráda, “The European subsistence crisis of 1845-1850: a comparative perspective", When the potato failed, 26.
} 
aastal nõudis düsenteeria rohkelt elusid nii Eesti- kui Liivimaal. Liivimaa kuberneri 1845. aasta aruandes öeldakse otsesõnu, et "närvipalaviku" ja "verise kõhutõve" (s.o düsenteeria) leviku põhjus on leivapuudus. ${ }^{77}$ Toidupuudust haiguste põhjusena tunnistas ka Eestimaa kuberner 1868.-69. aastal. Koduloomade massiline suremine 1845. aastal tulenes ennekõike korraliku sööda puudusest. ${ }^{78}$

1844. aastal, kui Eestis levisid toidupuudusest nõrgestatud talupoegade hulgas epideemiad, olid Euroopas head või isegi väga head saagid. Väga rikkalik oli saak ka Lõuna-Venemaal ja Odessasse voolas kokku palju vilja. ${ }^{79}$ 1867.-69. aastatel ei tundnud Euroopa üldiselt viljapuudust (küll aga osa Venemaast). Euroopa teraviljaturud olid juba 1840. aastateks integreerunud. ${ }^{80}$ Tootlikkuse kasv, transpordi- ja liikumisvõimaluste paranemine ning viljakaubanduse liberaliseerimine olid vähendanud näljahädade riski. Turg oleks pidanud suunama vilja sinna, kus seda vajati. Ometi kannatasid sajandi keskel nälga lisaks Baltikumile veel mitmed Euroopa piirkonnad. Ikaldusele järgnes nälg ja demograafiline tagasiminek sageli just teravilja eksportivates regioonides. ${ }^{81}$ Veelgi enam, näljaajal eksport jätkus ja mõnel pool isegi kasvas. ${ }^{82}$

Nobeli majanduspreemia laureaat Amartya Sen on selgitanud, miks "turumehhanismide kindlad uskujad sageli pidid pettuma, kui turg ei suutnud kohale toimetada kuigi palju [toitu]" ${ }^{83}$ Tema teooria ühiskonnagruppide erinevatest õigustest (entitlement approach) nälgimise põhjuste seletamisel on leidnud rakendamist üle kogu maailma ja erinevate ajastute puhul, kuid pälvinud ka rohkelt kriitikat. ${ }^{84}$ Seni teooria järgi ei

77 EAA, f. 296, n. 4, s. 1177.

78 Kuramaa kuberner märkis 1845 . a aruandes, et mingeid loomahaigusi seal "peaaegu" pole, kuid talupojad on sööda puudusel kaotanud kümneid tuhandeid lojuseid (LVVA, 1. f.,. 4. apr., 316. 1, 113.-19o. lp.). Ka Liivimaa Riigivarade Valitsus leidis, et loomad surevad mädanenud heina söömise tõttu ja seda ei saavat õigupoolest "taudiks" nimetada (EAA, f. 296, n. 4, s. 1003, l. 15, riigivarade valitsus kubermangu meditsiinivalitsusele 19.6.1845). Eriti ilmekalt tuleb see välja mõisates ja taludes otsa saanud loomade hulka võrreldes.

79 Kahk, Murrangulised neljakümnendad, 106.

80 Vanhaute, Paping, Ó Gráda, “The European subsistence crisis", 29; Federico, "When did European", 104.

81 Bass, "The crisis in Prussia", 194-195.

82 Preisimaal 1847 (Bass, "The crisis in Prussia”, 199). Sama juhtus ka nt Venemaal 1891. a enne väljaveokeelu kehtestamist (Robbins, Famine in Russia, 34, 37), 1695-97 Baltikumis jm.

83 Amartya Sen, Poverty and famines: an essay on entitlement and deprivation (Oxford University Press, 1981), 160.

84 Vt Stephen Devereux, "Sen's entitlement approach: critiques and counter-critiques", Oxford Development Studies, 29, 3, $2001<\mathrm{http}: / /$ www.sas.upenn.edu/ dludden/FamineMortality.pdf> (16.5.2013). 
tähenda viljapuudus ostujõulise nõudluse kasvu. Äärmist toidupuudust kannatanud inimestel puudub õigus peatoidusele, st neil pole turupõhistes vahetussuhetes toidu eest vastu pakkuda seda, mida turul piisavalt väärtustatakse. Pahatihti toob nälja kaasa tööjõu suhtelise hinna langus toidu suhtes ja tööpuudus. Turg ei juhi toiduaineid mitte sinna, kus on nende järele vajadus, vaid sinna, kus on ostujõuline nõudlus. ${ }^{85}$

Ka Baltikumis nappis eeskätt ostujõudu. Viljasaak ja sellest johtuda võiv viljapuudus oli talivilja puhul üsna pikalt etteprognoositav ega tulnud kätte kohe lõikuse järel. Vilja sissetoomiseks Läänemere piirkonna viljakaubanduskeskustest oli piisavalt aega peamiselt seetõttu, et üldjuhul puhkes tõsine nälg alles vähemalt kahe järjestikuse ikaldusaasta kordumisel. Liivimaal oli viljapuudus 1845 . aasta uudseviljani tegelikult rohkem suhteline kui absoluutne, sest 1844 . aasta saagist ja olemasolevast varuviljast jätkunuks nii toidu- kui ka seemneviljaks. ${ }^{86}$ Ometi puhkes nälg. Vilja saanuks väljast sisse osta, kui talurahvas olnuks ostujõuline. Ostujõu nõrkust ehk "siseturu igas mõttes ebasoodsat olukorda" märkasid ka kaasaegsed. ${ }^{87}$ Et vajaka jäi ostujõust, nähtub kõige ilmekamalt aga sellest, kuidas näljahädasid vaigistati: mõisad ja riik jagasid abivajajatele valdade kaudu toetuslaene vilja või raha näol. 1860. aastateks oli vallakassadesse kogunenud summade tõttu talurahva ostujõud tervikuna küll kosunud ja näiteks Saaremaal lasti lisaks riigikassast eraldatud 150 ooo rublale leivavilja muretsemiseks käiku ka 37967,33 rubla vallakassade raha, ${ }^{88}$ kuid valdade rahaga kaeti vaid väike osa näljaabi vajadusest. Vallakassad kaasati ka Põhja-Eestis. Eestimaa kuberneri Wilhelm von Ulrichi sõnul jaksanuks 1868. aasta lõikuseni vajamineva vilja isegi tavapäraste hindadega osta vaid üheksa kihelkonna vallad, kuigi vilja vajasid juurde 23 kihelkonna vallad. ${ }^{89}$

Puudustkannatava külarahva suutlikkust toetuslaenu tagasi maksta hindasid kaasaegsed väga madalaks. 1840. aastatel, kui kerkis küsimus vilja kohaletoomisest Riiast või väljastpoolt maakonna piire, peeti pisimaidki

\footnotetext{
85 Sen, Poverty and famines, 154-165.

86 EAA, f. 291, n. 1, s. 8270, 1. 32-33p, Liivimaa kuberner Balti kindralkubernerile 1.11.1844. Elanike aastane toiduviljavajadus oli sel ajal arvestuslikult 751835 setverti rukist ja 393249 setverti otri, seemnevilja oma 279619 ja 295 566, kokku 1093636 ja 880042 (LVVA, 1. f., 4. apr., 1762. 1., 15.-18. lp.). 1844. a koristati kubermangus kokku 676682 setverti tali- ja 1007973 setverti suvivilja.

87 LVVA, 3. f., 10. apr., 2. 1., 24v. lp., Liivimaa kuberneri 1844. a aruanne.

88 EAA, f. 296, n. 4, s. 2372, 1. 342-342p.

89 LVVA, 1. f., 12. apr., 290. 1., 25.-29v. lp., Eestimaa kuberner Balti kindralkubernerile 23.1.1868.
} 
veokulusid talurahvale üle jõu käivaiks..$^{90}$ Vene vili olnuks sisse tuues kallim kui kohalik, kuigi viimase hind oli tõusnud ennekuulmatult kõrgele, ${ }^{91}$ ja välismaa vili tulnuks omakorda kallim neist mõlemast. ${ }^{92}$

Kui 1840. aastatel oli Eesti küla vaene ja nälg üldine, puudutades nii pere- kui ka sulas- ja popsirahvast, siis 1868.-69. aasta oma oli juba üsna selgelt sotsiaalselt diferentseeritud. Kõige tõsisem hoop tabas vabadikke ning tööta jäänud sulasrahvast. Maata ja vähese maaga talurahva toidulaud oli väga kesine ka tavalistel aastatel. Kuna nemad olid kõige hinnatundlikumad, tõi hinnatõus endaga kiirelt kaasa nälja. ${ }^{93}$

Talurahva kesist ostujõudu teades puudus kaupmeestel huvi vedada vilja mujalt sisse. Väidetavalt puudus neil selleks ka vaba kapital. 1867. aasta sügisel pöördus Eestimaa kuberner Ulrich Tallinna kaupmeeste poole üleskutsega hankida "puudujääv" vili, mis aga ei teostunud vähese "ettevõtlikkuse" ja kapitali puudumise tõttu. ${ }^{94}$

Viljahinnad Euroopas olid keskajast peale olnud mitte lihtsalt nõudluse ja pakkumise tulemus, vaid viljaturg oli poliitiliselt konstrueeritud, seda läbistasid võimude tegevus ja ühiskondlikud normid, see oli sotsiaalse võitluse areen. Varauusaegses Euroopas kasutasid võimud poliitilistel ja sotsiaalsetel kaalutlustel tervet arsenali meetmeid viljahindade volatiilsuse vähendamiseks ning tarbimise stabiilsena hoidmiseks. ${ }^{95}$ Majandusliku liberalismi ideoloogia vaimus hakkasid aga valitsevad kihid neist abinõudest järk-järgult lahti ütlema. Mitte riiklik või kohalik võim ei suutvat tagada stabiilset varustatust toiduviljaga ja hindade võimalikult vähest kõikumist, vaid turujõudude vaba konkurents.

1840. aastate kriisi ajal käitusid Mandri-Euroopa riikide valitsused pragmaatiliselt ega lähtunud vabakaubanduse ideoloogiast, vaid piirasid vajadusel eksporti ja stimuleerisid importi. Sekkumine erines riigiti. ${ }^{96}$

\footnotetext{
90 EAA, f. 291, n. 1, s. 8270, 1. 89-9op, Liivimaa resideeriv maanõunik Balti kindralkubernerile 9.3.1845; LVVA, 29. f., 1. apr., 26. 1, 396.-396v. lp., Tartumaa 5. kihelkonnakohtunik kubernerile 11.8.1845.

91 LVVA, 29. f., 1 apr., 26. 1., 341. lp.

92 LVVA, 29. f., 1. apr., 1451. 1., 135.-137., 202.-206. lp., Liivimaa toitluskomisjoni protokollid 18.10 ja 26.11 .1845 .

93 Talurahva süvenev diferentseerumine ja alamate kihtide vaesumine iseloomustas 18.-19. sajandil kogu Euroopat (Vanhaute, Paping, Ó Gráda, “The European subsistence crisis", 18-19).

${ }^{94}$ LVVA, 1. f., 12. apr., 290. l., 25.-29v. lp., Eestimaa kuberner Balti kindralkubernerile 23.1.1868.

95 Persson, Grain Markets, 70-80.

96 Vanhaute, Paping, Ó Gráda, “The European subsistence crisis”, 31-32; Daly, “Something old", 63 .
} 
1840. aastate terava nälja tingimustes kerkis ka Baltikumis üles küsimus turu reguleerimisest. Balti aadel ja linnad olid traditsiooniliselt vaba viljakaubanduse poolt. Vana ja äraproovitud meetmena rakendas valitsus ekspordikeelde. 1841. ja 1844. aastal ei veetud Tallinna sadamast välja ühtki sälitist rukist. ${ }^{97}$ Liivimaal teadaolevalt sellist keeldu ei kehtestatud, mis on ka mõistetav, sest Riia kaudu voolas välja "võõras" vili. Nähtavasti mõjutas valitsuse otsuseid ka liberaalsemaid vaateid esindanud rahandusministri ametisse asumine 1843. aastal. 1846. aastal langetati ekspordi soodustamiseks väljaveotariife, ${ }^{98}$ kuigi nälg ei olnud veel täielikult järele andnud (riiklikku näljaabi anti isegi veel 1847. aastal) ja Riia börsi hinnad olid Euroopa suurenenud nõudluse tõttu tõusuteel.

Eestimaa kuberneri 1843. aasta aruandes märgitakse, et talivilja saadi kubermangus keskmiselt 2 ja $21 / 2$, kohati isegi alla 1 seemne ning suvivilja 4 seemet. Sellest hoolimata väljendab kuberner Johann von Grünewaldt pahameelt selle üle, et keiser oli lubanud vilja tollivaba sisseveo, sest selle loaga "tõkestatakse teravilja hinna tõusu [!] ja kohalikud viljavarud pole ammendunud". ${ }^{99}$ Keskvõimud soodustasid vilja, jahu, kartulite jm importi Balti sadamatesse sisseveotollide kaotamisega nii 1845 . kui 1868. aastal. ${ }^{100}$

Riiklikult oli vilja kättesaadavust võimalik reguleerida näiteks ka kehtestades viina väljaveokeelde ning piirates viina tootmist, milleks kulus suur osa mõisate teraviljasaagist. Veel 1860. aastate lõpul valmis umbes pool viinatoodangust viljast. Viinapõletamise piiramise küsimuse tõstatasid linnad ja Kuramaa rüütelkond 1845. aastal ning selle abinõu kiitis heaks Kuramaa kubermanguvalitsus, kuid Liivimaal kohtas see tugevat vastuseisu nii toitluskomisjoni, kuberneri kui ka kindralkuberneri poolt. Liivimaa toitluskomisjon leidis, et see "pole ei vajalik ega soovitav", sest takistaks kubermangu "sisemist ringlust" (st majandusringlust) ja kroonu viinahangete täitmist, vähendaks mõisarentnike tulusid, mõisate nuumhärjad jääksid ilma praagata, põllukultuur langeks, kartulist viina tegemise keelamine oleks mõisnikele "väga kahjulik" ja nn jookidemaksu ärajäämine annaks hoobi riigikassale. ${ }^{101}$ Kuberner Friedrich von Fölkersahm ja kindralkuberner Jevgeni Golovin muretsesid väga mõisate kõrtsitulude ja

\footnotetext{
97 Eesti talurahva ajalugu, 1, peatoim. Juhan Kahk (Tallinn: Olion, 1992), 398.

98 Strods, Razvitie, 45-46.

99 EAA, f. 29, n. 1, s. 4531, 1. 10.

100 LVVA, 29. f., 1. apr., 26. 1., 233. lp., keisri kinnitatud ministrite komitee 20.6.1845. a otsus; LVVA, 29. f., 1. apr., 208. 1., 69. lp., keisri 24.8.1868. a korraldus.

101 LVVA, 29. f., 1. apr., 1451. 1., 110.-114V., 117.-122. lp., toitluskomisjoni protokollid, 1. ja 5.10.1845.
} 
riigile laekuva jookidemaksu vähenemise pärast. ${ }^{102}$ Algatuse laitis maha ka ministrite komitee Peterburis.

Liivimaale veeti riikliku toetuslaenu korras suurtes kogustes vilja küll sisse, eriti massiliselt $1845-46$, kuid uurimist vajab küsimus, kui palju tulnuks seda juurde tuua siis, kui mõisate rukki- ja kartulisaaki oleks vähem intensiivselt viinaks põletatud ning otri õlleks pruulitud jm.

1840. aastate kriisi puhkedes püüdsid keskvõimud näljaabi jätta tervikuna kohalike mõisnike hooleks. Mitmesugustes ettekirjutustes kohustati mõisnikke nälgijaid laenuviljaga toetama ja korralduste täitmata jätmisel ähvardati neid karistada. ${ }^{103}$ Kuni 1845 . aastani lasuski näljaabi raskus mõisnikel. Liivimaa mõisnike toetuslaenud olid kohati päris prisked, talupoegadele jagati viljalaene sadade ja koguni tuhandete rublade väärtuses, anti ära suur osa mõisa rukkisaagist jne. ${ }^{104}$ Sama tegid ka Kuramaa mõisnikud..$^{105} 1845$. aastal päästis aga valitsus oma rahakraanid valla: Liivimaale eraldati sadu tuhandeid rublasid laenu, mille eest kreisisaadikud, sillakohtunikud ning ringkonnainspektorid ostsid Liivi- ja Eestimaa mõisatelt ning linnakaupmeestelt talupoegade tarbeks toidu- ja seemnevilja.

Vilja kokkuost kroonu toetuslaenu eest tekitas koheselt küsimuse piirhindade kehtestamisest. Liivimaa toitluskomisjoni laiendatud koosolekul 4. augustil 1845 . aastal teatas Liivimaa rüütelkonna resideeriv maanõunik Nicolaus Johann von Transehe, et rukki vakk maksab kõikjal rohkem kui komisjoni poolt varemalt piirhinnaks kehtestatud 1,7 rubla ning ei maksa oodata, et mõisavalitsused seda "oma kahjuks" odavamalt laenaks (õigemini müüks riigile), ning ta pani ette tõsta piirhind kahele rublale. Kohal viibinud kubermanguasutuste esindajad tuletasid talle meelde, et ka mõisnikele

\footnotetext{
102 LVVA, 29. f., 1. apr., 26. 1., 522., 569. lp.

103 Vt nt LVVA, 29. f., 1. apr., 1449. 1., 93. lp., toitluskomisjoni žurnaal 17.5.1841; LVVA, 3. f., 1. apr., 1897. 1., 62. lp.; ibid., 96. lp., kuberner kihelkonnakohtunikele 2.4.1842; LVVA, 3. f., 1. apr., 2153. 1., 67.-68. lp., Tartumaa 5. kihelkonnakohtunik kubernerile 13.3.1845; EAA, f. 291, n. 1, s. 8270, 1. 44-49, 424-428p, kuberner kindralkubernerile, 11.1 ja 22.11.1845. 104 LVVA, 29. f., 1. apr., 15. 1., 20.-21. lp., Suure-Konguta mõisavalitsus toitluskomisjonile, 26.12.1841; Tamme mõisa rentnik Louise Michelson väitis 25.7.1841 kirjas Liivimaa Kroonupalatile, et on andnud talupoegadele toetuslaenu vähemalt 800 rubla ulatuses (LVVA, 77. f., 11. apr., 915. 1., 4.-5. lp.). Räpina mõisnik andis 1842 laenu 3000 vakka rukist. 1845 kevadel ostis ta suviviljaseemet ja jahu 7000 rubla eest (LVVA, 29. f., 1. apr., 26. 1, 572.-572v. lp., 582, Räpina mõisnik kubernerile, 9.10.1845). Misso mõisnik toetas "mitme tuhande" rubla jagu (ibid., 213.-213v., 225.-225v. lp., Võru sillakohtunik toitluskomisjonile 24.6.1845). Kogu Vastseliina kihelkonna peale andis Liphart viljalaenu väidetavalt 16000 rubla väärtuses (EAA, f. 291, n. 1, s. 8277, 1. 8-9p, Aderkas kindralkubernerile, 13.6.1845). Mõnel pool andsid mõisarentnikud talupoegadele laenuks kogu saagi (LVVA, 29. f., 1. apr., 26. 1., 633--634. lp., Tartu 3. kihelkonnakohtunik kubernerile 12.10.1845).

105 EAA, f. 291, n. 1, s. 8273, 1. 32-34p, Balti kindralkuberner siseministrile 23.1.1846.
} 
on oluline, et talude põllud saaksid seemendatud ja ainult korraliku saagi korral on talupojad suutelised hakkama saama mõisapoolse näljaabita, kandma mõisakoormisi ning tasuma riigimakse. Kuberner Fölkersahm, riigivarade valitsuse ülem F. von Lilienfeldt ja rüütelkonna esindaja Campenhausen soostusid piirhinda tõstma 10 kopika võrra. Resideeriv maanõunik jäi endale kindlaks, kuid enamuse otsusel lisati vaka piirhinnale juurde siiski esialgu 10 kopikat. ${ }^{106}$

Lõpuks kehtestati Liivimaal riikliku laenu eest vilja kokkuostul rukki setverti piirhinnaks 7,5, odral 6 ja kaeral 3,8 rubla. ${ }^{107}$ Vallad ja nende vahendusel ka üksikud talupojad said toetuslaenu kätte ühiskäenduse tingimusel ${ }^{108}$ ja üldjuhul viljas, kuid tagasi pidid nad selle riigile maksma 20 aasta jooksul rahas, arvestusega, et viljaabi oli saadud kehtinud piirhindadega, kuigi viljahinnad olid tagasimaksete tegemise ajaks langenud poole võrra. Hiljem turuhinnad küll tõusid.

Üldiselt on arvatud, et hirm riikliku sekkumise ees ohjeldab hinnatõusu. ${ }^{109}$ Viis, kuidas Vene valitsus näljaabi korraldas, andis viljahindade tõusule aga hoogu juurde. ${ }^{110} 1868$. aasta sügisel otsustas Eestimaa toitluskomisjon vilja väljast sisse osta, sest vilja kokkuost kohapeal oleks tõstnud selle hinda. ${ }^{111}$ Liivimaa mõisnikel õnnestus 1845.-46. aastal suurtes kogustes vilja maha müüa tavalisest kaks korda kõrgema hinnaga, sest leidus kindel ostja - riik. Mõisapidajad kauplesid toitluskomisjoniga viljahinna pärast ega tahtnud seda piirhinnast odavamalt müüa. ${ }^{12}$ Mõisnike ärilistest kaalutlustest annab tunnistust ka see, et kui komisjon ei suutnud neile tähtaegselt tasuda, viisid nad osa lubatud vilja ladudest minema, ilma et oleksid komisjoni sellest isegi teavitanud. Seda tuli ette siiski üsna harva. ${ }^{113}$

Need mõisnikud, kes laenasid talupoegadele ise vilja ega müünud seda toitluskomisjonile kõrgeks kruvitud hindadega, said kahju. Leidus ka neid aadlipoliitikuid, kes ei pidanud silmas ärilisi huve, vaid pooldasid vilja kiiret

\footnotetext{
106 LVVA, 29. f., 1. apr., 1451. 1., 84.-86v. lp.

107 LVVA, 29. f., 1. apr., 1451. 1., 142.-145. lp., toitluskomisjoni protokoll 22.10.1845; ibid., 52. 1., 8.-9. lp., komisjoni ringkiri 14.4.1846.

108 EAA, f. 2054, n. 1, s. 1199, reglement, p. 1, 23.4.1846.

109 Persson, Grain markets, 82.

110 Vt ka Ermolov, Nashi neurozhai, 55.

111 EAA, f. 29, n. 2, s. 4759, Eestimaa kubermangu toitluskomisjon 3.1.1869.

112 LVVA, 29. f., 1. apr., 18., 20., 26. 1.

113 LVVA, 29. f., 1. apr., 18. 1., 116.-117., 152.-163V., 247.-247V., 250.-250v. lp., kreisisaadik August von Sivers toitluskomisjonile, 7.5.1846, 7.6.1846 ja 25.5.1847.
} 
kokkuostu Peterburist, ${ }^{114}$ ootamata ära hinnatõusu kohalikul turul. Võimalus vilja topelthinnaga müüa oli teretulnud, kuid see oli vaid üks kriisiga kaasnenud asjaoludest. 1830. aastate keskpaigas alanud ja vahepausidega kümmekond aastat väldanud ning ajaga süvenenud ja laienenud kriis tervikuna tekitas mõisnikele tõsiseid raskusi, sundides neid lõpuks mõisa ja talude suhted ümber korraldama.

Ka taluperemehed saanuks hinnatõusust kasu, kui toodangumaht poleks langenud sel määral, et neil enestel tuli vilja juurde osta. Olukord kujunes selliseks, et sisuliselt ostsid talud toitluskomisjoni vahendusel mõisatelt "järelmaksuga” välja enda tööriistade ja -loomadega ning teoliste tööjõuga haritud mõisaväljade põllusaagi, makstes vilja eest tavapärasest kaks korda kõrgemat hinda. Kuna vallad oli kohustatud toitma kõik oma liikmed (ka sulasrahva ja vabadikud), kuhjusid hiigelvõlad, mille tagasimaksmine langes peamiselt maaga vallaliikmete õlule. See laostas arvukalt talusid ja ühtlasi pingestas sotsiaalseid vahekordi külas. Viimasest annavad tunnistust valdade pöördumised võimude poole sooviga saata vabadikud vallast välja. ${ }^{115}$ 1868. aastal tabas Liivimaa mitmeid piirkondi juba uus näljahäda, kuigi mõnel pool polnud toibutud isegi eelmisest: veel 1870. aastate keskel ajatas valitsus 1840. aastatest pärit võlgade põhiosa ja tühistas kümnetesse tuhandetesse ulatunud maksmata intresse. ${ }^{116}$

Ilmselt osaliselt just 1840. aastate ebameeldivate kogemuste mõjul tahtis siseministeerium 1868. aastal, et ei jagataks toetuslaene, vaid pani 6. juuli salajases kirjas kuberneridele ette, et kubermanguvõimud jõuaksid kaupmeestega sellisele kokkuleppele, et nad müüksid abivajajatele vilja tavapärase hinnaga ja hinnavahe turuhinnaga kompenseeritakse neile toitluskomisjoni vms poolt ning arvatakse viljasaajaile võlaks. Päris vaesed ja ostujõetud saaksid toitluskomisjonilt talongid vilja ostmiseks. ${ }^{117}$ Kubermangujuhid ja aadliladvik said korraldusest aru nii, et tuleks leida kaupmehed, kes müüksid vilja tavahinnaga. Selliseid mõistagi ei leidunud.

Eestimaa rüütelkond oli 1868. aasta suve lõpus muretsenud valdadele toetuslaenudena väljajagamiseks või müügiks 12 ooo setverti vilja ning

114 LVVA, 29. f., 1. apr., 26. 1., 572.-572V., 582. lp., maanõunik Eduard von Richter kubernerile 9.10.1845. Vt ka maanõunike kolleegiumi palvet kroonu kulul vilja kokku osta 1844. aasta sügisel ja seda kevadel "mõõduka hinnaga" müüa (ibid., 29. f., 1. apr., 1450. 1., 82.-85v. lp., toitluskomisjoni žurnaal 5.10.1844).

115 LVVA, 29. f., 1. apr., 54. 1., 76.-76v. lp., Tartu 2. kihelkonnakohtunik komisjonile 1.1.1847; ibid., 29. f., 1. apr., 60. 1., 17.-17v. lp., Tartumaa 3. kihelkonnakohtunik kubernerile 19.10.1846; EAA, f. 2054, n. 1, s. 944.

116 LVVA, 29. f., 1. apr., 1872. l.; 1. f., 3. apr., 248. 1.

117 LVVA, 1. f., 12. apr., 290. 1., 177.-178. lp., siseminister Kuramaa kubernerile 6.7.1868; ibid., 470.-471. lp., siseminister kindralkubernerile 1.11.1868. 
kartis, et riigi sekkumine langetab hindu ja neil tuleb hangitud vili müüa odavamalt, kui nad ise olid selle saanud (toob kaasa "hukatuslikud tagajärjed"). Hirmunud aadlipoliitikud asusid võitlusse viljahindade "kunstliku" langetamise vastu ning maalisid märgukirjades võimudele mitmesuguseid ohte: vallandub spekulatsioon, vili tuleb nälgijatele anda igal juhul valdade kaudu, et üksiktarbija "ei kogeks kunstlikke hindu vahetult" ja välditaks ohte, mis võiksid provintsi majandusringlusele "kunstlikest" hindadest tuleneda. Talurahval võib tekkida ettekujutus, et riik on "kohustatud" neid toitma ja see mõjuks kui "kääritav haigusollus". ${ }^{118}$ Kuberner edastas rüütelkonna argumendid kindralkuberner Pjotr Albedinskile ilma ühegi omapoolse vastulauseta. ${ }^{119}$

\section{Kokkuvõtteks}

Raudtee-eelsel ajastul sõltusid viljahinnad Eesti alal olulisel määral nõudlusest ja pakkumisest siseturul; murrang tuli raudteevõrgustiku arenguga, kui saagikus kohalikel põldudel kujundas hinda juba vähem kui viljasaagid Vene sisekubermangudes. Sel ajal ületasid maaturu hinnad ekspordihindu. Siinne viljaturg oli integreerunud, mida näitab nii hindade vähene varieerumine kui ka nende sarnane liikumine eri maakondades. Ainult taastumine järskudest muutustest nõudluse ja pakkumise vahekorras ei kulgenud sarnaselt. 1840. aastate ja 1867.-69. aasta ikalduse ajal ei suutnud turg suunata vilja äärmist puudust kannatanud küladesse ega leevendada nälga, sest puudus ostujõuline nõudlus. Ainuüksi tõkete kõrvaldamine kaubahoovuste vabalt liikumiselt ei taganud elanikkonna varustatust viljaga. Riigivõimud, kes hoidusid väljaveo ja viinatootmise piiramisest, mis suurendanuks pakkumist siseturul, pidid nälja vaigistamiseks eraldama priskeid toetuslaene, millega vili nii kohapeal mõisatest kui ka väljast kokku osteti. Sajandi keskel jagasid talurahvale viljalaene ka mõisnikud, kuid seisid kubermangujuhtide toel nii siis kui ka hiljem edukalt vastu igasugustele enda majandushuve riivata ähvardanud näljaabimeetmetele.

\footnotetext{
118 LVVA, 1. f., 12. apr., 290. 1., 285.-290. lp., maanõunik von zur Mühleni märgukiri 12.9.1868.

119 LVVA, 1. f., 12. apr., 290. 1., 278.-281v. lp., Eestimaa kuberner Balti kindralkubernerile 14.9.1868.
} 
Lisa 1. Rukki ja rukkijahu maakondlikud hinnaindeksid Eestimaal ja Liivimaa Eesti osas $1875-1898$

\begin{tabular}{|c|c|c|c|}
\hline \multicolumn{4}{|c|}{ Eestimaa $=100(1$ setvert rukkijahu=9,3 rubla) $1875-1886$} \\
\hline Harju & Viru & Järva & Lääne \\
\hline 98,9 & 97,2 & 97,8 & 106,5 \\
\hline \multicolumn{4}{|c|}{ Liivimaa Eesti osa $=100(1$ setvert rukkijahu $=9,5$ rubla $) 1875-1887$} \\
\hline Tartu & Võru & Viljandi & Pärnu \\
\hline 93,7 & 107,3 & 98,4 & 96,8 \\
\hline \multicolumn{4}{|c|}{ Lõuna-Eesti $=100(1$ puud rukist $=0,78$ rubla $) 1889-1898$} \\
\hline Tartu & Võru & Viljandi & Pärnu \\
\hline 99,8 & 98 & 101,4 & 100,9 \\
\hline
\end{tabular}

Koostamise alus: Cenȳ na proviant i furazh po svedeniyam Intendantskogo vedomstva (Vremennik Central'nogo statisticheskogo komiteta Ministerstva vnutrennikh del, 4) (S.-Peterburg: 1889); Materialȳ po statistike khlebno torgovli, vȳp. 2 (S.-Peterburg, 1899).

Lisa 2. Rukki ja suvivilja (kaera) saagikus seemnetes ja setverti hind rublades Liivimaa Eesti osas 1840-1884

\begin{tabular}{|c|c|c|c|c|c|c|c|c|c|c|c|c|c|c|c|c|c|c|c|c|}
\hline & \multicolumn{4}{|c|}{ Tartumaa } & \multicolumn{4}{|c|}{ Võrumaa } & \multicolumn{4}{|c|}{ Viljandimaa } & \multicolumn{4}{|c|}{ Pärnumaa } & \multicolumn{4}{|c|}{ Saaremaa } \\
\hline & 童 & 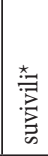 & 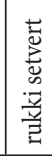 & 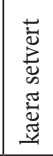 & 胥 & 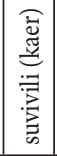 & 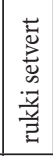 & 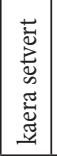 & $\frac{n}{3}$ & 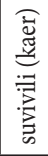 & 量 & 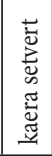 & $\frac{n}{3}$ & 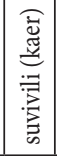 & 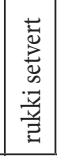 & 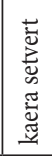 & 鸹 & 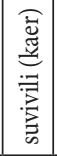 & 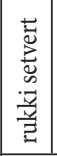 & 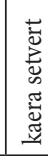 \\
\hline & \multicolumn{2}{|c|}{ seemet } & \multicolumn{2}{|c|}{ rubla } & \multicolumn{2}{|c|}{ seemet } & \multicolumn{2}{|c|}{ rubla } & \multicolumn{2}{|c|}{ seemet } & \multicolumn{2}{|c|}{ rubla } & \multicolumn{2}{|c|}{ seemet } & \multicolumn{2}{|c|}{ rubla } & \multicolumn{2}{|c|}{ seemet } & \multicolumn{2}{|c|}{ rubla } \\
\hline 1840 & & & 5,5 & 5,8 & & & & & & & & & & & & & & & & \\
\hline 1841 & 3 & 4 & 6,75 & 3,5 & 3,3 & 4 & 7,75 & 4,24 & 2,5 & 4 & 7,7 & 3,75 & 3 & 5 & 6,5 & 2,75 & 5,5 & 3,5 & 5,5 & 2,95 \\
\hline 1842 & 5,5 & 4,3 & 4,3 & 2,5 & 4 & 4 & 7 & 3 & 5,25 & 5 & 5,55 & 2,8 & 5 & 4 & 4,5 & 2,6 & 5 & 3,5 & 4,4 & 2,15 \\
\hline 1843 & 2,66 & 3,9 & 5,5 & 3,5 & & & 7,5 & 4,25 & & & 6,75 & 3,5 & & & 6,2 & 3,15 & & & 5,6 & 2,4 \\
\hline 1844 & 2,8 & 3,3 & 5,5 & 2,8 & 3 & 4 & 5,5 & 2,5 & 3 & 3 & 4,3 & 3,4 & 3 & 5 & 5,5 & 3,1 & 4,75 & 5 & 5,7 & 2,8 \\
\hline 1845 & 2,25 & 3,2 & 6,15 & 3,9 & 2 & 2,5 & 7,5 & 5 & 2,5 & 2 & 0 & 5,25 & 3 & 3 & 7 & 4,2 & 5 & 2 & 6,5 & 5,25 \\
\hline 1846 & 3,6 & 3,16 & 6 & 3 & 3,75 & 2,79 & 7 & 4 & 4 & 4 & 7,87 & 5,25 & 4,53 & 3,7 & 6,5 & 3,5 & 5,37 & 4,75 & 6,5 & 5,5 \\
\hline 1847 & 4,3 & 3,3 & 5,5 & 3,25 & 4,75 & 3,8 & 7 & 3,5 & 4 & 5 & 6,75 & 4,25 & 5 & 5,4 & 6 & 3,3 & 5,5 & 5 & 7 & 3,9 \\
\hline 1848 & 5,5 & 4 & 4,4 & 2,9 & 5 & 4 & 5 & 3 & 5 & 5 & 6,75 & 4,25 & 7 & 6 & 4,5 & 2,5 & 4,66 & 3,75 & 5,25 & 2,7 \\
\hline 1849 & 4,2 & 3,8 & 4,1 & 3 & 3,43 & 3,9 & 4,5 & 2,1 & 4 & 5 & 7,5 & 4,25 & 5 & 6,3 & 4,25 & 2,1 & 4,5 & 4,3 & 4,37 & 2,25 \\
\hline 1850 & 3,8 & 4 & 4 & 2,3 & 3,1 & 3,5 & 4,8 & 2,4 & 4 & 5 & 6,5 & 4 & 5,5 & 4,6 & 4,25 & 2,25 & 5 & 4,5 & 4,75 & 2,5 \\
\hline 1851 & 4 & 3,66 & 3,9 & 2,3 & 3 & 3 & 5,1 & 3 & 3 & 4 & 6,5 & 4 & 4 & 4,75 & 4,6 & 2,75 & 4 & 3,25 & $\mathrm{n}$ & $\mathrm{n}$ \\
\hline 1852 & 5,5 & 4 & 4,2 & 3,45 & 4 & 3,5 & 4,8 & 3,6 & 4 & 4 & 6,5 & 4 & 5 & 4 & 5,25 & 3,25 & 5 & 3 & 5,25 & 3 \\
\hline 1853 & 5 & 4 & 4,7 & 3,1 & 4 & 3,75 & 6 & 3,3 & 3 & 3 & 6,5 & 4 & 4 & 4 & 6,5 & 3,6 & 3,66 & 4 & 7 & 4 \\
\hline 1854 & 5 & 4 & 5,7 & 4,1 & 3,25 & 2,5 & 7,2 & 4,8 & 4,5 & 3,5 & 8,5 & 5,5 & 5,5 & 5 & 5,75 & 4,5 & \begin{tabular}{|l|}
5 \\
\end{tabular} & 4 & 5 & 4 \\
\hline 1855 & 5,25 & 2,25 & 7 & 6 & 3 & 2 & 7,5 & 5,7 & 3,5 & 2 & 7,5 & 6,5 & 5,5 & 3,5 & 6,5 & 6 & 5 & 2,5 & 5 & 4,5 \\
\hline 1856 & 5 & 5,5 & 6,83 & 6,43 & 3 & 3,25 & 7,8 & 3,3 & 5,75 & 4 & 7,5 & 5 & 5,5 & 5,5 & 8 & 4 & 4,25 & 6 & 7 & 4 \\
\hline 1857 & 6 & 4 & 5,7 & 3,2 & 3 & 3 & 6,6 & 3,6 & 4,5 & 4 & 7,5 & 5 & 5,75 & 4 & 6,5 & 3,15 & 4,5 & 3,5 & 7 & 3,45 \\
\hline 1858 & 6 & 3,5 & 4,9 & 3,9 & 5,5 & 2,25 & 6 & 4,2 & 5 & 3 & 7,5 & 5 & \begin{tabular}{|l|}
6 \\
\end{tabular} & 3,5 & 6,15 & 4,2 & 5 & 3 & 6,3 & 3,5 \\
\hline
\end{tabular}




\begin{tabular}{|c|c|c|c|c|c|c|c|c|c|c|c|c|c|c|c|c|c|c|c|c|}
\hline & \multicolumn{4}{|c|}{ Tartumaa } & \multicolumn{4}{|c|}{ Võrumaa } & \multicolumn{4}{|c|}{ Viljandimaa } & \multicolumn{4}{|c|}{ Pärnumaa } & \multicolumn{4}{|c|}{ Saaremaa } \\
\hline & $\frac{\mathscr{a}}{2}$ & 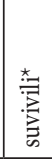 & 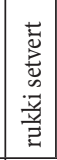 & 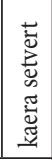 & $\frac{a}{3}$ & 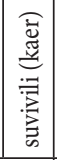 & 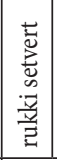 & 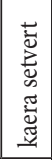 & 量 & 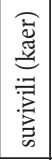 & $\frac{n}{3}$ & 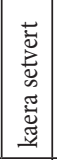 & 童 & 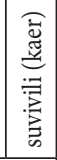 & 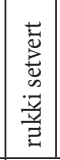 & 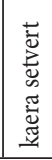 & 童 & 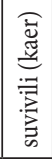 & 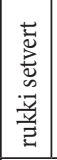 & 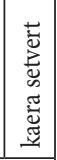 \\
\hline & \multicolumn{2}{|c|}{ seemet } & \multicolumn{2}{|c|}{ rubla } & \multicolumn{2}{|c|}{ seemet } & \multicolumn{2}{|c|}{ rubla } & \multicolumn{2}{|c|}{ seemet } & \multicolumn{2}{|c|}{ rubla } & \multicolumn{2}{|c|}{ seemet } & \multicolumn{2}{|c|}{ rubla } & \multicolumn{2}{|c|}{ seemet } & \multicolumn{2}{|c|}{ rubla } \\
\hline 1859 & 5 & 6 & 5,2 & 3 & 5,5 & 4,75 & 5,1 & 4,2 & 4,75 & 5 & 7,5 & 5 & 6 & 5,5 & 5,7 & 3,6 & 4,5 & 2,5 & 5,75 & 3,5 \\
\hline 1860 & 6 & 5 & 6,6 & 3,6 & 4,5 & 5 & 6 & 3,75 & 4,5 & 4 & 6,25 & 5 & 5,5 & 5 & 6,15 & 3,8 & 5 & 2 & 6,8 & 3,9 \\
\hline 1861 & 5 & 6 & 8,7 & 4,3 & 4 & 5 & 7 & 4,2 & 3,5 & 5 & 8,5 & 4,5 & 4,5 & 4 & 8 & 4,5 & 4 & 3 & 7,25 & 4,3 \\
\hline 1862 & 6 & 7 & 7,5 & 5,75 & 5 & 4,5 & 8,5 & 4,6 & 4,5 & 5,75 & 9,5 & 4 & 6 & 5,75 & 7,5 & 4 & 6 & 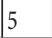 & 6,6 & 3,75 \\
\hline 1863 & 6 & 7 & 6,35 & 3 & 4,5 & 6 & 7,2 & 3,3 & 5,7 & 7,3 & 6,75 & 3 & 6 & 5,5 & 6 & 3,5 & 5 & 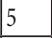 & 6 & 3 \\
\hline 1864 & 7 & 6,5 & 6,2 & 3,1 & 5,5 & 5 & 6 & 2,7 & 5 & 5 & 6,5 & 3,5 & 5,5 & 5 & 10,5 & 3,7 & 6 & 5 & 6 & 4 \\
\hline 1865 & 4 & 5,5 & 8,65 & 4,2 & 4 & 6 & 8,7 & 5 & 4 & 6 & 8 & 5 & 4 & 4,5 & 8 & 4,75 & 3 & $t^{ \pm}$ & 8 & 5 \\
\hline 1866 & 6 & 7 & 7,5 & 3,9 & 6 & 6 & 7,5 & 3,75 & 5 & 7 & 9 & 5,5 & 6 & 5,5 & 8 & 4,5 & 6 & 7 & 7 & 4,5 \\
\hline $1867^{* *}$ & 4,5 & 5 & 11,9 & 5,25 & 5 & 5 & 9,9 & 5,1 & 5 & 6 & 9 & 5,75 & 4 & 3 & 12 & 6,5 & 3 & 5 & 9,5 & 4,5 \\
\hline 1868 & 4 & 3 & 9 & 6,15 & 5 & 2,5 & 13,5 & 6,6 & 5 & 4 & 15 & 9 & 3 & 2 & 14 & 7 & 2 & 2,5 & 13 & 7 \\
\hline 1869 & 4,7 & 5 & 11,5 & 5,2 & 6 & ${ }^{0}$ & 10,5 & 5,5 & 5 & 0 & 15 & 9 & 3 & $0^{0}$ & 9 & 5,5 & 5 & 5,5 & 8 & 4 \\
\hline 1870 & 4,4 & 3,8 & 9,9 & 3,75 & 5,45 & 5,39 & 14 & 7,5 & 5,94 & 5,67 & 16,5 & 7 & 5,6 & 4,37 & 10,75 & 5,5 & 4,86 & 3,68 & 7,5 & 3,75 \\
\hline 1871 & 4 & 2,8 & 11 & 7,5 & 4 & 2,8 & 10,5 & 5,5 & 5,4 & 2,5 & 16,5 & 5 & 5,4 & 2,5 & 10,75 & 5,5 & 3,2 & 3,8 & 8,5 & 5,1 \\
\hline 1872 & 6,8 & 3,6 & 11 & 6,5 & 7,7 & 3,5 & 10,5 & 6,5 & 6,6 & 3,5 & 12 & 6 & 7,9 & 3,3 & 10 & 6,5 & 5,2 & 4,1 & 8,5 & 5,5 \\
\hline 1873 & 6,6 & 4,2 & 9,75 & 6,5 & 6,4 & 3,5 & 8,1 & 5,7 & 7,5 & 5 & 11 & 6 & 5,4 & 2,7 & 8,5 & 6,5 & 4,3 & 3,4 & 7,5 & 5,75 \\
\hline 1874 & 6,2 & 4,8 & 7,7 & 5 & 6,7 & 4,3 & 8,1 & 5,7 & 7,4 & 6,1 & 9 & 5,5 & 5,6 & 4,5 & 8 & 5,75 & 4,6 & 4,4 & 7,5 & 6 \\
\hline 1875 & 5,6 & 3,2 & 7,85 & 4,95 & 5,8 & 2,7 & 8,1 & 5,7 & 7 & 3,6 & 0 & 5,5 & 5,6 & 4,3 & 8 & 6,25 & 3,2 & 4,5 & 8,5 & 6 \\
\hline 1876 & 2,8 & 4,5 & 9,6 & 5,1 & 2,9 & 5 & 8,4 & 5,7 & 1,5 & 5,4 & 9 & 5,5 & 2,1 & 4,8 & 11 & 3 & 2,5 & 4,9 & 10,5 & 7 \\
\hline 1877 & 5,4 & 4,7 & 10 & 5,6 & 5,4 & 2,9 & 9,25 & 6 & 5,9 & 4,5 & 9 & 5,5 & 4,9 & 5,6 & 11 & 6 & 4,1 & 5,6 & 9,5 & 5,5 \\
\hline 1878 & 6,1 & 4,8 & 9,5 & 5,5 & 5 & 4,9 & 9,65 & 6 & 7,9 & 5,5 & 9 & 6 & 5,8 & 3,8 & 11 & 0 & 3,6 & 3,9 & 9,5 & 5,5 \\
\hline 1879 & 3,7 & 3,1 & 9,25 & 5,3 & 3,6 & 2,9 & 9,25 & 6 & 4,2 & 2,9 & 12,5 & 6,3 & 3,7 & 4,1 & 11 & 6 & 4,2 & 4,8 & 9,5 & 5,5 \\
\hline 1880 & 4,7 & 4 & 11,85 & 6,25 & 4,5 & 3,5 & 11,25 & 6,75 & 5,2 & 3,6 & 14 & 8 & 5,2 & 3,8 & 11 & 6,5 & 3,6 & 4 & 12 & 6,5 \\
\hline 1881 & 3,5 & 5,2 & 13 & 6,2 & 3,3 & 4,9 & 11,25 & 6,75 & 3,9 & 4,8 & 15 & 6 & 3,4 & 3,8 & 14,5 & 7 & 3,5 & 4,3 & 14,5 & 10,55 \\
\hline 1882 & 7,5 & 3,1 & 10 & 5,7 & 7,3 & 2,8 & 11,25 & 6,75 & 8,6 & 3,9 & 15 & 6 & 7,3 & 2,4 & 14,5 & 7 & 5 & 4,3 & 14,5 & 7 \\
\hline 1883 & 5,6 & 6,2 & 9,5 & 4,87 & 5,3 & 4,5 & 11,25 & 6,75 & 6,5 & 6,2 & 15 & 6 & 4,5 & 4,5 & \begin{tabular}{|l|}
9 \\
\end{tabular} & 5 & 4,4 & 6 & 11,12 & 7 \\
\hline 1884 & 5,5 & 4,3 & 10,3 & 5,45 & 6,3 & 4,4 & 11,25 & 6,75 & 5,2 & 3,6 & 15 & 6 & 5 & 3,8 & 9 & 5 & 5 & 5,3 & 11,12 & 7 \\
\hline
\end{tabular}

* 1870. aastani suvivili; 1871 . aastast kaer.

** 1867. a - aasta keskmised hinnad.

Koostamise alus: EAA, f. 296, n. 1, s. 24; 26; 28;30; 32; 34; 36; 38; 42; 43; 45-47; 49-51; 55; 60; n. 4 ; s. $369 ; 403 ; 934 ; 1179 ; 1563 ; 1780 ; 2273 ; 2387 ; 2407 ;$ n. 5 , s. $99 ; 484 ; 855 ; 1283 ; 1644 ; 1988$; 2766; 3254; 3787; 4481; f. 949, n. 1, s. 206; 299; 327; 329; LVVA, 1. f., 4. apr., 317.-320., 1770. 1; 3. f., 1. apr., 1897., 2153. l.; 4. apr., 185. 1.; 10. apr., 5. l.; 29. f., 1. apr., 217., 220., 223., 228., 230., 233., 237.-239., 242., 254. l. 
Lisa 3. Rukki ja suvivilja (kaera) saagikus seemnetes ja setverti hind rublades Eestimaal 1841-1886

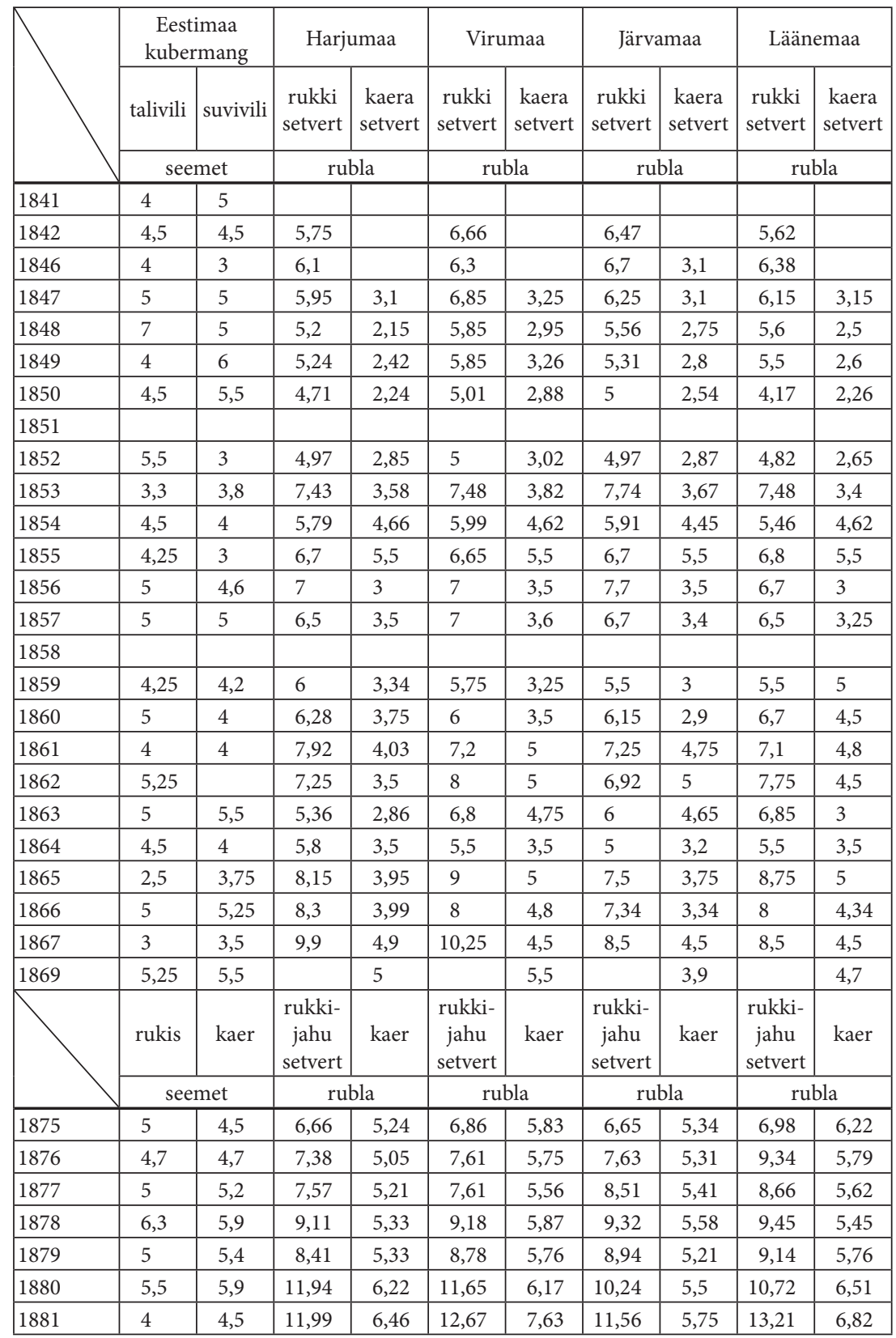




\begin{tabular}{|l|c|c|c|c|c|c|c|c|c|c|}
\hline & \multicolumn{2}{|c|}{$\begin{array}{c}\text { Eestimaa } \\
\text { kubermang }\end{array}$} & \multicolumn{2}{|c|}{ Harjumaa } & \multicolumn{2}{c|}{ Virumaa } & \multicolumn{2}{c|}{ Järvamaa } & \multicolumn{2}{c|}{ Läänemaa } \\
\cline { 2 - 12 } & rukis & kaer & $\begin{array}{c}\text { rukki- } \\
\text { jahu } \\
\text { setvert }\end{array}$ & kaer & $\begin{array}{c}\text { rukki- } \\
\text { jahu } \\
\text { setvert }\end{array}$ & kaer & $\begin{array}{c}\text { rukki- } \\
\text { jahu } \\
\text { setvert }\end{array}$ & kaer & $\begin{array}{c}\text { rukki- } \\
\text { jahu } \\
\text { setvert }\end{array}$ & kaer \\
\cline { 2 - 13 } & \multicolumn{2}{|c|}{ seemet } & \multicolumn{2}{|c|}{ rubla } & \multicolumn{2}{c|}{ rubla } & \multicolumn{2}{c|}{ rubla } & \multicolumn{2}{c|}{ rubla } \\
\hline 1882 & 5,2 & 4 & 9,72 & 6,1 & 10,14 & 6,29 & 9,89 & 5,65 & 10,74 & 6,53 \\
\hline 1883 & & & 9,73 & 6,17 & 8,11 & 5,91 & 8,77 & 5,56 & 10,66 & 6,44 \\
\hline 1884 & 4,3 & 4,5 & 9,66 & 6,22 & 8,45 & 5,93 & 8,96 & 5,5 & 10,64 & 6,31 \\
\hline 1885 & 4,5 & 3,6 & 9,43 & 6,46 & 8,84 & 6,39 & 9,83 & 6,25 & 10,25 & 6,24 \\
\hline 1886 & 5,4 & 4,6 & 8,76 & 6,04 & 8,58 & 6,31 & 9,07 & 5,87 & 10,02 & 6,22 \\
\hline
\end{tabular}

Koostamise alus: EAA, f. 29, n. 1, s. 4526; 4527; n. 2, s. 4742; 4759; 4827; 4849; 4883; 4912; 4937; 4966; 4991; 5006; 5042; 5051; n. 3, s. 2677; 3712; 4070; 4351; 4353-436o; n.8, s. 559; f. 291, n. 1, s. 10462; 10846; 11029; 11191; 13383; 13678; LVVA, 1. f, 4. apr., 317. l.; rukkijahu setvert ja kaera setvert 1875-86 Ceny na proviant i furazh (vt lisa 1); rukki saagikus 1852-66 Artur Vassar, Uut maad otsimas (Tallinn, 1975), 14; Obzor Éstlyandskoi gubernii za 1886 gg (Revel, 1887).

Lisa 4. Rukki ja kaera saagikus seemnetes ning rukkijahu ja kaera setverti hind Liivimaa Eesti osas 1875-1887

\begin{tabular}{|c|c|c|c|c|c|c|c|c|c|c|c|c|c|c|c|c|c|c|c|c|}
\hline & \multicolumn{4}{|c|}{ Tartumaa } & \multicolumn{4}{|c|}{ Võrumaa } & \multicolumn{4}{|c|}{ Viljandimaa } & \multicolumn{4}{|c|}{ Pärnumaa } & \multicolumn{4}{|c|}{ Saaremaa } \\
\hline & $\frac{\mathscr{n}}{\vec{Z}}$ & $\stackrel{\check{\Xi}}{\ddot{\Xi}}$ & $\begin{array}{l}\frac{\vec{z}}{\vec{J}} \\
: \frac{\vec{z}}{\vec{z}} \\
\frac{3}{\vec{z}} \\
\end{array}$ & 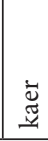 & $\underset{\sim}{\stackrel{a}{Z}}$ & 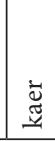 & 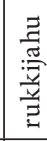 & $\stackrel{\check{\Xi}}{\ddot{\Xi}}$ & $\stackrel{\mathscr{Z}}{\vec{z}}$ & 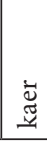 & 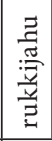 & $\begin{array}{r}\dot{\Xi} \\
\ddot{\Xi}\end{array}$ & $\underset{\vec{z}}{\vec{z}}$ & $\stackrel{\check{\Xi}}{\check{\Xi}}$ & 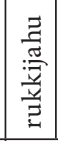 & $\begin{array}{l}\check{\Xi} \\
\ddot{\Xi}\end{array}$ & $\frac{\mathscr{n}}{\Xi}$ & $\stackrel{\check{\Xi}}{\ddot{\Xi}}$ & 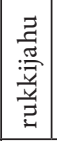 & 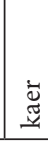 \\
\hline & \multicolumn{2}{|c|}{ seemet } & \multicolumn{2}{|c|}{ rubla } & \multicolumn{2}{|c|}{ seemet } & \multicolumn{2}{|c|}{ rubla } & \multicolumn{2}{|c|}{ seemet } & \multicolumn{2}{|c|}{ rubla } & \multicolumn{2}{|c|}{ seemet } & \multicolumn{2}{|c|}{ rubla } & \multicolumn{2}{|c|}{ seemet } & \multicolumn{2}{|c|}{ rubla } \\
\hline 1875 & 5,6 & 3,2 & 7,6 & 4,97 & 5,8 & 2,7 & 7,8 & 5,7 & 7 & 3,6 & 9 & 5,5 & 5,6 & 4,3 & 9 & 6,12 & 3,2 & 4,5 & 7,75 & 6,12 \\
\hline 1876 & 2,8 & 4,5 & 8,46 & 5,62 & 2,9 & 5 & 8 & 5,72 & 1,5 & 5,4 & 0 & $5-$ & 2,1 & 4,8 & 8,09 & 5,87 & 2,5 & 4,9 & 9,42 & 6,12 \\
\hline 1877 & 7,4 & 4,7 & 8,56 & 5,72 & $p, 4$ & 2,9 & 8,54 & 6 & 5,9 & 4,5 & & (3) & 4,9 & 5,6 & 9,58 & 5,44 & 4,1 & 5,6 & 9,67 & 5,5 \\
\hline 1878 & 6,1 & 4,8 & 8,67 & 5,81 & 5 & 4,9 & 9,45 & 6 & 7,9 & 5,5 & 9 & 5,79 & 5,8 & 3,8 & 9,58 & 6 & 3,6 & 3,9 & 9,31 & 5,5 \\
\hline 1879 & 3,7 & 3,1 & 7,74 & 5,2 & 26 & 2,9 & 9,25 & 6 & 4,2 & 2,9 & 0 & 6,04 & 3,7 & 4,1 & 9,58 & 6 & 4,2 & 4,8 & 9,25 & 5,5 \\
\hline 1880 & 7 & 4 & 10,63 & 6,19 & 4,5 & 3,5 & 10,92 & 6,62 & 5,2 & 3,6 & 9,22 & 6,33 & 5,2 & 3,8 & & 6,37 & & 4 & 10,06 & 5,75 \\
\hline 1881 & 3.5 & 5,2 & 11,66 & 6,73 & 3.3 & 4,9 & 11,25 & 6,75 & 3,9 & 4,8 & & 6 & 3,4 & 3,8 & & 6,96 & 3,5 & 4,3 & 12,55 & 8,11 \\
\hline 1882 & 7,5 & 3,1 & 10,44 & 5,7 & 7,3 & 2,8 & 11,25 & 6,75 & 8,6 & 3,9 & 10,99 & 6 & 7,3 & 2,4 & 10,43 & 7 & 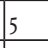 & 4,3 & 10,63 & 6,93 \\
\hline 1883 & 5,6 & 6,2 & 9,16 & 5,69 & 5,3 & 4,5 & 11,25 & 6,75 & 6,5 & 6,2 & & 6 & 4,5 & 4,5 & & 6,83 & 4,4 & 6 & & 7 \\
\hline 1884 & 5,5 & 4,3 & 9,23 & 5,08 & 63 & 4,4 & 11,25 & 6,75 & 5,2 & 3,6 & 9,82 & 6,08 & 5 & 3,8 & 8,67 & 5,33 & 5 & 5,3 & 11,2 & 7 \\
\hline 1885 & 5,4 & 3,4 & 8,23 & 5,66 & 4,3 & 2,8 & 11,25 & 6,75 & 5,5 & 3,1 & 11,1 & 6 & 4,2 & 1,9 & 10,52 & 6,16 & 2,8 & 2,5 & 11,1 & 6,2 \\
\hline 1886 & & & 8,13 & 5,47 & & & 11,25 & 6,75 & & & 9,6 & 5,83 & & & 8,52 & 6,83 & & & 10,95 & 6,66 \\
\hline 1887 & 7,3 & 4,9 & 8,13 & 3,72 & 6,2 & 4 & 11,25 & 6,75 & 7,3 & 4,7 & 7,12 & 5 & 7 & 4,4 & 8,45 & 6,25 & 6,4 & 4,2 & 7,75 & 5,63 \\
\hline
\end{tabular}

Koostamise alus: EAA, f. 296, n. 1, s. 6o; 66; 73; f. 296, n. 5, s. 484; 855; 1283; 1644; 1988; $2766 ; 3254 ; 3787 ; 4481$; rukkijahu setvert ja kaera setvert $1875-86$ Ceny na proviant i furazh (vt lisa 1). 
Lisa 5. Rukki ja kaera hinna variatsioonikoefitsient Eesti alal 1847-1886

\begin{tabular}{|l|c|c|c|c|}
\hline & $1847-1850$ & $1853-1856$ & $1862-1865$ & $1883-1886$ \\
\hline rukis & 0,08 & 0,06 & 0,07 & 0,09 \\
\hline kaer & 0,067 & 0,056 & 0,068 & 0,062 \\
\hline
\end{tabular}

Koostamise alus: vt lisad 2 ja 3. Standardhälve on arvutatud täispopulatsiooni põhjal.

AвSTRACт: Local grain prices in Estonia and price influencing factors, $1840-1900$

The article examines the prices of rye and oats on local markets in 18411900 and discusses the factors affecting them. In Estonian and international scholarly literature, the grain prices have generally been studied on the basis of data from cities. Instead, this article focuses on local markets and their integration. International historiography considers it to be an important issue that is very difficult to address. Local grain prices are discussed from the peasant's point of view. Different sections of the rural population could act as buyers or sellers on the grain market, and farms could become buyers during bad harvests.

Crop yields and export prices are considered the two most important factors affecting the internal market prices in the short run. The changes in nominal prices over the decades and price differentials between the Estonian districts (Kreise) are examined. Price level convergence and similar price dynamics in different regions give evidence of significant market integration. The first is measured by the coefficient of variation and the second by the correlation coefficient. The coefficient of variation was rather insignificant and did not change over the decades under consideration, and the districts had similar price trends for rye and oats. Only recovery from sharp changes in supply and demand did not proceed in the same way. In the pre-railway time, the regional prices in Estonia were largely determined by demand and supply on the domestic market; breakthrough came with the development of railway transportation. In the pre-railway time, the local prices in the Estonian districts exceeded export prices. The 
development of a railway network made the local crop yields have much less impact on the local prices than the yields in Russia Proper.

One central question regarding any famine is whether markets functioned to ease the famine or to exacerbate the shortage. In the nineteenth century, the Baltics were an agricultural surplus region despite the fact that the area was repeatedly struck by famines until the end of the 1860 os. The third section of the article discusses why the market failed to ease the deficit in food consumption and what stance was taken by the governing elites in relation to the market and price regulation. In the crisis years, the market failed to move sufficient amounts of cereals into famine-stricken areas, since the need for food there was not translated into effective demand because of lack of market-based entitlement and a shortage of purchasing power. State authorities avoided actions to limit exports and refused to ban distillation, which both would have significantly increased the supply on the internal market. Their main anti-crisis initiative was to distribute advance loans to the needy. The grain was bought up from merchants and the local lords of the manors and paid for by state resources.

During the crises in the 1840 and 1860 s the grain prices doubled, and in the 184 os the lords of the manors could make profit from selling their grain stocks to the state for disbursal to needy peasants. The authorities, however, also forced the lords of the manors to give relief loans to their peasants in the mid-century. With the support of guberniya authorities (Governors and Governor-Generals), the Baltic nobilities could effectively avert any attempts of direct market regulation and price control.

KEYWORDS: 19th century, economic history, Baltic provinces, Estonia, grain prices, famines, crop yields, market integration and regulation.

KeRsti LuST (b. 1976) is an independent scholar.*

\footnotetext{
${ }^{*}$ Correspondence: Institute of History and Archaeology, University of Tartu, Ülikooli 18, 50090 Tartu, Estonia. E-mail: kersti_lust@yahoo.com
} 